\title{
Pteridófitas da Reserva Rio das Pedras, Mangaratiba, RJ, Brasil ${ }^{1}$
}

\author{
Claudine M. Mynssen² \& Paulo G. Windisch ${ }^{3}$
}

\begin{abstract}
Resumo
(Pteridófitas da Reserva Rio das Pedras, Mangaratiba, RJ, Brasil) A Reserva Rio das Pedras situa-se no Município de Mangaratiba, estado do Rio de Janeiro, nas coordenadas $22^{\circ} 59^{\prime} \mathrm{S}$ e $44^{\circ} 05^{\prime} \mathrm{W}$, com cerca de 1.260 ha. É uma Reserva Particular do Patrimônio Natural (RPPN), de propriedade do Clube Mediterranée, compreendendo um remanescente de Floresta Atlântica e altitudes que variam de 20 a $1.050 \mathrm{~m}$ alt., em diversos estágios de regeneração decorrentes de ações antrópicas distintas. A análise da flora pteridofítica indica a ocorrência de 17 famílias, 45 gêneros e 117 espécies. São apresentadas chaves de identificação e comentários para os táxons encontrados.
\end{abstract}

Palavras-chave: Pteridófitas, Floresta Atlântica, Rio de Janeiro.

\begin{abstract}
(Pterodophytes of the Rio das Pedras Reserve, Mangaratiba, RJ, Brazil) Rio das Pedras Reserve is located in the Municipality of Mangaratiba, State of Rio de Janeiro, in the coordinates $22^{\circ} 59^{\prime} \mathrm{S}$ and $44^{\circ} 05^{\prime} \mathrm{W}$, with about 1260 ha. It is a Private Reserve (RPPN), which belongs to Club Mediterranée. The area is a remainder of Atlantic Pluvial Forest of several stages in succession, with altitudes from 20 to 1050 meters. The analysis of the pteridophyte flora indicates the occurrence of 17 families, 45 genera and 117 species. Identification keys for families and species of the area are presented.
\end{abstract}

Key-words: Pteridophyte, Atlantic Forest, Rio de Janeiro.

\section{INTRODUÇÃo}

As pteridófitas estão representadas no continente americano por cerca de 3.250 espécies, das quais 3.000 estão presentes no Neotrópico, sendo que no sudeste/sul do Brasil ocorrem aproximadamente 600 espécies, a maioria localizada nas florestas úmidas da Serra do Mar (Tryon \& Tryon 1982). No passado, a costa atlântica brasileira era formada por uma faixa continua de Floresta Atlântica que se estendia do norte ao sul do Brasil, mas atualmente este bioma é um dos mais ameaçados pelos constantes desmatamentos e seus remanescentes encontram-se representados em boa perte por florestas secundárias. Como já indicado por Smith (1962), Tryon (1972), Mori et al. (1981), entre outros autores, tais remanescentes fazem parte dos principais centros de endemismo e especiação na América Tropical.

Ao longo dos anos, vários trabalhos sobre as pteridófitas foram desenvolvidos a fim de se conhecer os remanescentes de Floresta Atlântica no estado do Rio de Janeiro. Destes destacam-se Vellozo (1825-1827), que elaborou a Flora Fluminensis; Rizzini (195354) com a sua Flora Organensis; Brade (1956) que estudou a flora de Itatiaia. Mais recentemente têm-se os trabalhos de Mynssen \& Sylvestre (2001), Mynssen et al. (2002), Sylvestre (1997 a, b), Santos et al. (2004).

Este trabalho foi desenvolvido na Reserva Rio das Pedras (RRP), situada no Município de Mangaratiba, representando um remanescente de Floresta Atlântica da região litorânea, ao sul do estado do Rio de Janeiro.

Este estudo teve como objetivo contribuir para o conhecimento da flora pteridofítica do estado do Rio de Janeiro a partir do levantamento de um remanescente de Floresta Atlântica. Além disso, elaborar chaves dicotômicas para a identificação dos táxons encontrados.

Artigo recebido em 08/2004. Aceito para publicação em 10/2004.

${ }^{1}$ Parte de Dissertação de Mestrado, MN/ UFRJ (CAPES)

${ }^{2}$ Pesquisadora, Instituto de Pesquisa Jardim Botânico do Rio de Janeiro. Rua Pacheco Leão 915, Jardim Botânico, Rio de Janeiro - RJ - Brasil CEP 22460-030. cmynssen@jbrj.gov.br

${ }^{3}$ Prof. Titular, PPG - Biologia, UNISINOS, São Leopoldo - RS - Brasil CEP 90022-000 Bolsita PC/ CNPq. 


\section{Material e Métodos}

A Reserva Rio das Pedras (RRP), localizada no Município de Mangaratiba (2259'S $44^{\circ} 05^{\prime} \mathrm{W}$ ) na região sul do estado do Rio de Janeiro, com acesso pelo km 55 da Rodovia BR101 Rio/Santos. Trata-se de uma Reserva Particular do Patrimônio Natural (RPPN) de propriedade do Club Mediterranée do Brasil e compreende uma área de 1.260 ha e altitudes que variam de 20 a 1.050 m alt. (Fig. 1). Vários trechos desta área foram utilizados no cultivo de bananeiras e atualmente ainda são encontrados resquícios desta cultura em algumas regiões até cerca de $500 \mathrm{~m}$ alt. A bacia do rio Grande corta a RRP como um divisor de sua área e seus afluentes tornam algumas regiões úmidas com grande número de espécies herbáceas, epífitas e árvores de até $40 \mathrm{~m}$ de altura e cerca de $45 \mathrm{~cm}$ DAP (diâmetro a altura do peito). No interior da floresta ocorrem afloramentos rochosos cerca de $10 \mathrm{~m}$ de altura cobertos por espécimes herbáceos, área com dossel fechado e bosque sombrio. No Pico do Corisquinho, localizado a
$450 \mathrm{~m}$ alt., há grande incidência solar e a vegetação é xerófita. O clima é subquente (Nimer, apud Vidal 1995) com temperaturas médias anuais de $22^{\circ} \mathrm{C}$ e temperatura máxima absoluta de $38^{\circ} \mathrm{C}$. A grande variação de altitude próxima ao litoral é responsável pela alta precipitação pluviométrica no local, sendo que a época de precipitação máxima corresponde aos meses de dezembro, janeiro e fevereiro.

O levantamento florístico foi realizado durante dois anos com excursões quinzenais e coletas ao acaso ao longo das dez trilhas existentes e suas adjacências. Estima-se que aproximadamente $40 \%$ da área total da Reserva tenha sido amostrada. Os espécimes foram herborizados segundo técnicas usuais (Windisch 1992 a) e incorporados aos acervos dos Herbários da Universidade Santa Úrsula (RUSU) e do Jardim Botânico do Rio de Janeiro (RB).

Os táxons foram identificados a partir de bibliografia específica indicada ao final do tratamento de cada família. Adotou-se o sistema de classificação proposto por Kramer \& Green

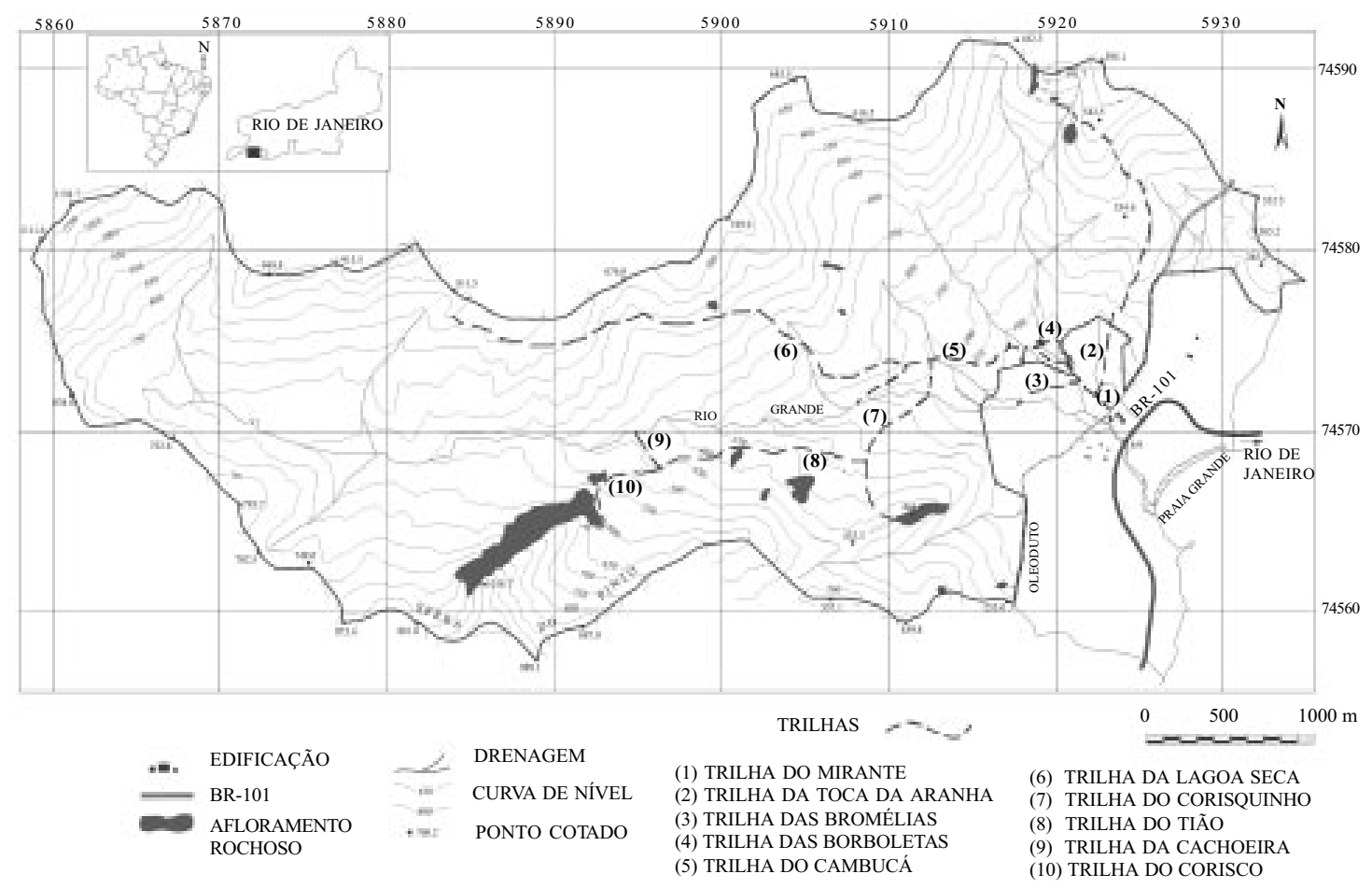

Figura 1 - Mapa da Reserva Rio das Pedras, Mangaratiba, RJ. Modificado de Agrofoto Aerofotogrametria S/A (1999). 
(1990) com as seguintes exceções: em Cyatheaceae utilizou-se a proposta de Lellinger (1987) e em Vittariaceae adotou-se Crane (1997). As abreviaturas de autores seguem Pichi-Sermolli (1996). Os comentários foram feitos a partir das obsevações de campo, de aspectos relevantes encontrados na literatura e foram mencionadas as faixas de altitude ( $\mathrm{m}$ alt.) onde os espécimes foram observados.

\section{Resultados e Discussão}

A flora pteridofítica da Reserva Rio das Pedras é composta por 117 espécies, pertencentes a 45 gêneros e 17 famílias.

\section{Chave para identificação das famílias encontradas}

1- Caule com micrófilos, estrutura foliar uninérvia

2- Microfilo com uma só forma, disposição radial Lycopodiaceae

2'- Microfilo com duas ou mais formas, disposição dorsiventral

1'-Caule com megafilos, estrutura foliar com nervuras ramificadas Selaginellaceae

3- Mesofilo foliar constituído por uma única camada de células; indúsio tubular ou bilabiado Hymenophyllaceae

3'- Mesofilo foliar constituído por mais de uma camada de células; indúsio nunca tubular ou bilabiado

4- Planta com caule globoso; estípulas presentes ao redor da inserção do estípite; esporângios organizados em sinângios Marattiaceae

4'-Planta com caule nunca globoso; estípulas ausentes; esporângios nunca organizados em sinângios

5- Fronde pseudo-dicotomicamente dividida

Gleicheniaceae

5'-Fronde nunca pseudo-dicotomicamente dividida

6- Plantas em geral arborescentes, caule ereto Cyatheaceae

6'- Plantas herbáceas ou subarborescente, caule ereto, decumbente ou escandente

7- Plantas com soros localizados em duas pinas basais modificadas formando espigas ou nas margens modificadas do segmento ..... Schizaeaceae

7'- Plantas com soros de formas diferentes

8- Soros cobrindo inteiramente a face abaxial da fronde, frondes dimorfas Lomariopsidaceae

8'-Soros geralmente não cobrindo inteiramente a face abaxial da fronde, ou se cobrindo frondes monomorfas

9- Caule com escamas totalmente clatradas, soros alongados a elípticos

10- Soros indusiados, venação livre Aspleniaceae

10'-Soros exindusiados, venação anastomosada Vittariaceae

9'-Caule com escamas não clatradas, soros alongados ou cobrindo completamente a face abaxial de fronde ou, se clatradas, soros arredondados 11- Soros lineares margeando os dois lados da costa Blechnaceae

11'- Soros não lineares e nunca com esta disposição

12- Estípite articulado ao caule, sobre filopódio, apresentando nítida área de inserção Polypodiaceae

12'- Estípite não articulado ao caule, não formando filopódio, sem área nítida de inserção

13- Lâmina pinada, pina articulada Nephrolepidaceae 13'-Lâmina simples, pinada ou pinado-pinatífida, pina não articulada 14- Caule coberto por pêlos; soros marginais

Dennstaedtiaceae

14'-Caule coberto por escamas ou, se coberto por tricomas, então soros não marginais
Rodriguesia 55 (85): $125-156.2004$ 
15- Soros marginais ou acompanhando as nervuras e sem indusios ou se cobrindo a superfície abaxial da lâmina com indumento farináceo branco Pteridaceae

15'-Soros nunca marginais ou acompanhando as nervuras e indusiados ou, se cobrindo a superfície abaxial da lâmina, nunca com indumento farináceo branco

16- Estípite somente com dois feixes vasculares Thelypteridaceae

16'- Estípite com um ou mais de dois feixes vasculares Dryopteridaceae

\section{Aspleniaceae}

A família Aspleniaceae possui cerca de 700 espécies distribuídas preferencialmente na região tropical (Tryon \& Stolze 1993). Segundo Sylvestre (2001), as espécies brasileiras ocorrem desde o nível do mar até $2.700 \mathrm{~m}$, sendo mais freqüentes entre 300 e $2.000 \mathrm{~m}$. Ainda segundo esta autora, não há uma concordância em relação ao número de gêneros, embora tenham sido propostos diversos sistemas de classificação para a família, no Brasil reconhece os gêneros Antigramma (3 spp) e Asplenium (69 spp).

\section{Chave para identificação das espécies}

1- Fronde simples

9. Asplenium serratum

1'- Fronde decomposta

2- Lâmina com ápice radicante; estípite e raque brilhantes

7. Asplenium radicans

2'- Lâmina com ápice não radicante; estípite e raque foscas

(A. radicans var. uniseriale)

3- Caule reptante, dorsiventral

4- Estípite revestido por escamas na base; raque glabra; caule verde

11. Asplenium triquetrum

4'- Estípite totalmente revestido por escamas; raque com escamas; caule castanho

10. Asplenium serra

3'- Caule ereto

5- Indúsio espesso

2. Asplenium auritum

5'-Indúsio membranáceo

6- Nervuras furcadas, exceto na porção distal da pina; aurícula do lado acroscópico da pina sobrepondo a raque

1. Asplenium auriculatum

6'- Nervuras simples, exceto na porção basal da pina; aurícula nunca sobrepondo a raque

7- Pina subdimidiada, partindo da raque em ângulo muito agudo

6. Asplenium pulchellum

7'- Pina subequilateral, partindo da raque em ângulo quase reto

8- Estípite curto (2-5 cm compr.); pinas extremamente reduzidas na base

9- A la do raque interrompida no ponto de inserção da pina; base acroscópica das pinas auriculadas 5.Asplenium pteropus

9'- Ala do raque não interrompida no ponto de inserção da pina; base das pinas bi-auriculadas

4. Asplenium mucronatum

8'-Estípite longo (7-10 cm compr.); pinas pouco reduzidas na base

10- Fronde verde claro; caule ( $3 \mathrm{~mm}$ diâm.) e estípite delgado; pina com ápice agudo a brevemente obtuso

3. Asplenium clausenii

10'-Fronde verde escuro, caule (5-7 mm diâm.) e estípite robusto; pina com ápice obtuso

8. Asplenium regulare 
1. Asplenium auriculatum Sw., Kongl. Vetensk. Acad.. Handl. 1817: 68. 1817.

Planta rupícola, ocorre em ambientes muito úmidos e sombreados, geralmente às margens dos rios, entre 150 e $250 \mathrm{~m}$ alt. Foi observado a formação de extensos tapetes recobrindo as pedras, com indivíduos férteis a partir de $2 \mathrm{~cm}$ de altura, muitos formando estolões.

Material examinado: trilha do Cambucá, 6.V.1997, Mynssen 98, 102; id., 30.XI.1996, Sylvestre 1231, 1232, 1250; Poço do Cambucá, 27.VIII.1998, Sylvestre 1357; trilha do Corisco, 21.I.2000, Nonato 695; trilha do Corisquinho, 15.IX.1996, Braga 3505.

\section{Asplenium auritum Sw., J. Bot. (Schrader)} 1800 (2): 52.1801.

Ocorre como rupícola sobre rochas cobertas por húmus, em ambientes parcialmente expostos ao sol, podendo formar estolões. Foi observada entre cerca de 250 e $400 \mathrm{~m}$ alt. Material examinado: trilha do Corisquinho, 3.VI.1997, Mynssen 127, 125; trilha para a Toca da Aranha, 26.VIII.1998, Sylvestre 1352.

\section{Asplenium clausenii Hieron., Hedwigia 60:} 241. 1918.

Planta rupícola, pouco freqüente, observada em ambiente sombreado no subbosque, entre 250 e $350 \mathrm{~m}$ alt. Esta espécie é semelhante a Asplenium regulare, mas segundo Sylvestre (2001), A. clausenii diferencia-se, entre outras características, pelos caules e estípites mais delgados, pelas pinas com ápices agudos a brevemente obtusos e pela coloração verde clara da lâmina foliar. Material examinado: trilha do Corisquinho, 3.VI.1997, Mynssen 135.

\section{Asplenium mucronatum C. Presl, Delic.} Prag. 1: 178. 1822.

Ocorre preferencialmente epífita, mas também pode ser encontrada como rupícola em pedras recobertas por uma camada de húmus, em ambientes muito sombreados e úmidos, entre 400 e $650 \mathrm{~m}$ alt. As frondes pendentes, pina membranáceas com base bi-auriculada e raque estreitamente alada não interrompida na inserção das pinas caracterizam esta espécie e a distinguem de $A$. pteropus.

Material examinado: trilha da Lagoa Seca, 27.V.1997, Braga 4093; trilha da Toca da Aranha, 21.X.1997, Braga 4367; id., 24.XI.1998, Bovini 1587.

5. Asplenium pteropus Kaulf., Enum. Filic. 170. 1824.

Planta preferencialmente epífita, mas também pode ocorrer como rupícola. É muito freqüente em regiões sombreadas, entre $200 \mathrm{e}$ $400 \mathrm{~m}$ alt. Trata-se de uma espécie semelhante a A. mucronatum, mas possui frondes eretas, pina herbáceas com base auriculada e ala da raque interrompida no ponto de inserção da pina. Material examinado: trilha do Cambucá, 30.XI.1996, Sylvestre 1244, 1245; id., 19.X.1996, Bovini 1074, 1080; trilha da Lagoa Seca, 26.V.1998, Mynssen 168, 178; id., 26.VIII.1998, Dória 3; id., 27.VIII.1998, Sylvestre 1360, 1362.

6. Asplenium pulchellum Raddi, Opusc. Sci. 3:291. 1819.

Plantas rupícola ou saxícola, freqüentemente encontrada em áreas sombreadas às margens dos rios, entre 100 e $200 \mathrm{~m}$ alt.

Material examinado: margem do rio Grande, 20.I.2000, Nonato 683; trilha do Cambucá, 30.XI.1996, Sylvestre 1233; id., 25.I.1998, Braga 4742; trilha do Corisquinho, 3.VI.1997, Mynssen 134; id., 1.XII.1996, Braga 3680; 26/04/1997, Braga 3980; trilha para a Toca da Aranha, 26.VIII.1998, Sylvestre 1351, $1353,1359$.

\section{Asplenium radicans var. uniseriale} (Raddi) L. D. Gómez, Brenesia, 8: 53. 1976.

Planta terrícola, ocorre em áreas sombreadas em densas populações entre 400 e 600 $\mathrm{m}$ alt., nos trechos onde a mata é mais fechada e preservada. A partir da gema prolífera no ápice da raque, pode originar novos indivíduos que se estabelecem quando o raque torna-se pesado e toca o solo. 
Material examinado: trilha da Lagoa Seca, 12.VII.1997, Braga 4212; id., 13.VIII.1999, Mynssen 282; id., 27.VIII.1998, Sylvestre 1364.

8. Asplenium regulare Sw., Kongl. Vetensk. Acad. Handl. 67. 1817.

Planta preferencialmente rupícola, sobre rochas com camada de húmus, mas pode algumas vezes ser encontrada como terrícola ou epífita, sempre em ambientes muito sombreados. É muito freqüente, principalmente entre 400 e 600 malt., porém é registrada desde $100 \mathrm{~m}$ de altitude. Material examinado: trilha do Cambucá, 30. XI.1996, Sylvestre 1252; trilha do Corisco, 21.I.2000, Nonato 701; trilha da Lagoa Seca, 26.V.1998, Mynssen 188; id., 26.VIII.1998, Santos 1072; id., 26.VIII.1998, Dória 4; trilha da Toca da Aranha, 4.XI.1997, Braga 4445.

9. Asplenium serra Langsd. et Fisch., Ic. Fil. 16. t. 19.1810.

Planta saxícola, ciófila, pouco freqüente, apenas encontrada no interior da mata próximo ao cume do morro Corisco a cerca de $900 \mathrm{~m}$ alt. Material examinado: trilha do Corisco, 18.I.2001, Braga 6628.

10. Asplenium serratum L., Sp. Pl. ed. 2. 1709. 1753.

Planta preferencialmente epífita, eventualmente rupícola, ocorrendo no interior da mata bastante sombreada, entre 200 e $650 \mathrm{~m}$ alt. Trata-se de uma espécie com potencial ornamental, por apresentar suas frondes inteiras, fasciculadas, eretas e de verde intenso. Material examinado: trilha do Cambucá, 30.XI.1996, Sylvestre 1239; trilha da Toca da Aranha, 26.VIII.1998, Sylvestre 1355.

11. Asplenium triquetrum N. Murak. et R. C. Moran, Ann. Missouri Bot. Gard., 80(1):31. 1993.

Planta rupícola, em rochas desprovidas de húmus, somente observada às margens dos rios, em locais muito sombreados e que freqüentemente recebem borrifos d'água, entre 150 e $300 \mathrm{~m}$ alt. $\mathrm{O}$ caule, a raque e o pecíolo verdes são muito característicos desta espécie. Material examinado: trilha do Cambucá, 6.V.1997, Mynssen 103; id., 30.XI.1996, Sylvestre 1237, 1263; Poço do Cambucá, 27.VIII.1998, Sylvestre 1358; trilha do Corisco, 21.I.2000, Nonato 697; trilha para a Toca da Aranha, 26.VIII.1998, Sylvestre 1354.

Referências: Sehnem 1963; Sehnem 1968 a; Sylvestre 2001.

\section{Blechnaceae}

A família Blechnaceae está amplamente distribuída pelo mundo, constituída por nove gêneros (Tryon \& Stolze 1993). O gênero Blechnum possui cerca de 150 espécies sendo que 50 ocorrem nas Américas (Tryon \& Tryon 1982).

\section{Chave para identificação das espécies}

1- Plantas subarborescentes; estípite com escamas lineares, nigrescente

1. Blechnum brasiliense

1'- Plantas nunca subarborescentes; estípite com escamas lanceoladas ou oblongo-lanceoladas, castanhas

2- Caule rizomatoso, reptante

5. Blechnum serrulatum

2'- Caule ereto a decumbente

3 - Lâmina pinada, pina apical conforme

2. Blechnum fraxineum

3'-Lâmina pinatífida ou pelo menos com pina apical pinatífida

4- Segmentos basais reduzidos (2 ou 3), totalmente adnatos, não deflexos

4. Blechnum polypodioides

4'-Segmentos basais não reduzidos, livres, curtamente peciolulados a parcialmente sésseis, geralmente deflexos 3. Blechnum occidentale 
1. Blechnum brasiliense Desv., Ges. Naturf. Freunde Berlin Mag. Neuesten Entdeck. Ges. Naturk. 5: 330. 1811.

Planta terrícola, ocorrendo em ambientes muito ensolarados nas regiões mais degradadas, onde predomina o estrato herbáceo, entre $100 \mathrm{e}$ $300 \mathrm{~m}$ alt. Trata-se de uma espécie com potencial ornamental, com folhas rosuladas que podem ultrapassar $1 \mathrm{~m}$ de comprimento.

Material examinado: trilha do Cambucá, 30.XI.1996, Sylvestre 1254.

2. Blechnum fraxineum Willd., Sp. Pl. ed. 4, 5: 413. 1810.

Planta rupícola ou saxícola, sobre rochas com substratos arenosos ou com húmus, em ambientes muito sombreados e úmidos, constantemente borrifadas por água. Esta espécie é muito freqüente nas margens do rio Grande, especialmente entre 200 e $350 \mathrm{~m}$ alt.

Material examinado: trilha do Cambucá, 6.V.1997, Mynssen 104; id., 30.XI.1996, Sylvestre 1235.

3. Blechnum occidentale L., Sp. P1. 2: 1077. 1753.

Planta terrícola, sobre barrancos que margeiam as trilhas, formam grandes populações que habitam preferencialmente as áreas mais abertas e degradadas, entre $70 \mathrm{e}$ $350 \mathrm{~m}$ alt. Esta espécie apresenta uma grande variação morfológica e muitas vezes observase associada a Blechnum polypodioides.

Material examinado: margem do rio Grande, 20.I.2000, Nonato 690; trilha do Cambucá,
30.XI.1996, Sylvestre 1255; id., 14.IX.1996, Braga 3488; trilha do Corisquinho, 3.VI.1997, Mynssen 122; trilha da Toca da Aranha, 22.X.1997, Mynssen 160.

4. Blechnum polypodioides Raddi, Opusc. Sci. 3: 294. 1819.

Geralmente ocorre como terrícola em barrancos às margens das trilhas, em ambientes mais abertos e com maior luminosidade, associada Blechnum occidentale. Foi observada entre 70 e $250 \mathrm{~m}$ de altitude.

Material examinado: margem do rio Grande, 20.I.2000, Nonato 691; trilha do Cambucá, 30.XI.1996, Sylvestre 1260.

5. Blechnum serrulatum Rich., Actes Soc. Hist. Nat. Paris 1: 114. 1792.

Planta terrícola, ocorre em ambiente seco às margens da trilha, em local degradado e com muita incidência solar. É pouco freqüente, foi observada a aproximadamente $100 \mathrm{~m}$ alt.

Material examinado: trilha do Mirante, 26.VIII.1998, Mynssen 203.

Referências: Murillo 1968; Sehnem 1968b; Kazmirczak 1999.

\section{Cyatheaceae}

A família Cyatheaceae possui cerca de 500 espécies (Tryon \& Tryon 1982). Lellinger (1987) propõe cinco gêneros para a família Cyatheaceae sensu stricto representados na região neotropical, sendo Cyathea o maior deles.

\section{Chave para identificação das espécies}

1- Estípites com escamas lineares, com seta apical nigrescente; soros indusiados 1. Alsophila sternbergii

1'-Estípites com escamas oblongo-acuminadas, sem seta apical nigrescente; soros sem indúsio

2- Pina-raque sem espinhos; pínulas com lobos obtusos, margem inteira ... 2. Cyathea glaziovii

2'- Pina-raque com espinhos; pínulas com lobos agudos, margem serreada 3. Cyathea microdonta 
1. Alsophila sternbergii (Sternb.) D. S. Conant, J. Arnold Arbor. 64 (3): 371.1983.

Planta arborescente, geralmente ocorre próxima a outros indivíduos formando touceiras, em áreas parcialmente sombreadas, entre 200 e $400 \mathrm{~m}$ alt. Fernandes (1997) chama a atenção para a marcante deciduidade das folhas, o que não foi observado na área.

Material examinado: trilha do Cambucá, 14.IX.1996, Bovini 1032; id., 27.VIII.1998, Mynssen 206; trilha da Toca da Aranha, 29.IX.1998, Mynssen 234.

2 Cyathea glaziovii (Fée) Domin, Pteridophyta 262. 1929.

Planta arborescente, habita locais parcialmente sombreados no interior da mata. Foi observada aproximadamente entre 200 e 500 m alt. Segundo Fernandes (1997), esta espécie é próxima de Cyathea dichromatolepis (Fée) Domin, mas diferencia-se por possuir escamas castanhas concolores, lanceoladas com ápice longamente acuminado e pínulas com incisões mais profundas.

Material examinado: trilha do Cambucá, 30.XI.1996, Sylvestre 1230; trilha da Toca da
Aranha, 21.X.1997, Braga 4348; id., 11.I.1999, Mynssen 241.

3. Cyathea microdonta (Desv.) Domin, Pteridophyta 263. 1929.

Planta arborescente, ocorre em locais muito abertos e ensolarados, às margens das trilhas, a partir de 70 até $400 \mathrm{~m}$ alt. Os espinhos da pinaraque são muito característicos e permitem que esta espécie seja prontamente identificada no campo. De acordo com as observações feitas por Fernandes (1997), esta espécie cresce tanto em vegetação primária como secundária, sendo tipicamente tropical de terras baixas.

Material examinado: trilha do Mirante, proximidades do Mirante, 17.VIII.1996, Braga 3406.

Referências: Sehnem 1978; Fernandes 1997.

\section{Dennstaedtiaceae}

A família Dennstaedtiaceae possui cerca de 175 espécies que estão compreendidas em 20 gêneros. Está amplamente distribuída no mundo e, embora seja predominantemente pantropical, possui alguns elementos boreais ou de regiões sul temperadas (Tryon \& Stolze 1989).

\section{Chave para identificação das espécies}

1- Soros lineares 4. Pteridium aquilinum (P. aquilinum var. arachnoideum)

1 '- Soros globosos ou reniformes

2- Indúsio abrindo-se em direção a porção interna do segmento 3. Hypolepis repens

2'- Indúsio abrindo-se em direção a margem

3- Segmentos basais das pinas centrais alternos, eixos dos penúltimos segmentos alados ..... 1. Dennstaedtia bipinnata 3'-Segmentos basais das pinas centrais opostos, eixos dos penúltimos segmentos não alados 2. Dennstaedtia dissecta

1. Dennstaedtia bipinnata (Cav.) Maxon, Proc. Biol. Soc. Wash. 51: 39. 1938.

Planta terrícola, às margens da trilha em ambiente sombreado, é pouco freqüente. Pode ser distinta pela lâmina cartácea, brilhante com segmentos estéreis dentados.

Material examinado: trilha da Lagoa Seca, 26.V.1998, Mynssen 191.
2. Dennstaedtia dissecta (Sw.) Moore, Index Fil. 305. 1861.

Planta terrícola, ocorre em regiões sombreadas no interior da mata densa, é freqüente entre 400 e $500 \mathrm{~m}$ alt.

Material examinado: trilha da Cachoeira após a entrada para a trilha do Corisco, 6.I.2000, Mynssen 303; id., 21.I.2000, Santos 1387; trilha da Lagoa Seca, 12.VII.1997, Braga 4204. 
3. Hypolepis repens (L.) C. Presl, Tent. Pterid. 162. 1836.

Planta terrícola, freqüente nas áreas mais abertas e ensolaradas, às margens da trilha, junto ao capim colonião e em regiões em revegetação, entre a faixa de 100 até cerca de $200 \mathrm{~m}$ alt. Segundo Mickel \& Beitel (1988), esta é a espécie mais freqüente do gênero Hypolepis na América. Na maioria dos espécimes examinados nos herbários visitados observaram-se espinhos ou tubérculos na raque e no pecíolo, porém os materiais coletados na Reserva Rio das Pedras eram inermes, o que também foi verificado por Sehnem (1972) nos espécimes do Paraná, Santa Catarina e Rio Grande do Sul. Gruber (1981, apud Tryon \& Tryon 1982) estudou e mapeou o sistema caulinar desta espécie e verificou que a extensão do caule e o número de frondes emitidas demonstravam o potencial para o crescimento desta planta. Isto foi observado em alguns trechos na Reserva Rio das Pedras onde esta espécie apresenta crescimento clonal.

Material examinado: trilha do Cambucá, 30.XI.1996, Sylvestre 1224; id., 6.I.2000,
Mynssen 299; id., 20.I.2000, Santos 1370; trilha do Mirante, 27.VIII.1998, Mynssen 227; id., 22.III.1999, Mynssen 259.

\section{Pteridium aquilinum var. arachnoideum} (Kaulf.) Brade, Zeitsch. Deut. Ver. Wissen. Kunst. 1: 56. 1920.

É uma espécie terrícola e muitas vezes se apoia sobre as plantas adjacentes, cobrindoas. Está presente nas áreas ensolaradas e degradadas a $80 \mathrm{~m}$ alt. De acordo com Windisch (1992a), trata-se de uma espécie invasora e que pela grande quantidade de alcalóides é tóxica se ingerida.

Material examinado: trilha do Mirante, 26.VIII.1998, Nonato 543.

Referências: Tryon 1960, 1964; Sehnem 1972; Tryon \& Tryon 1982; Mickel \& Beitel 1988.

\section{Dryopteridaceae}

A família Dryopteridaceae possui distribuição cosmopolita e a grande maioria das espécies cresce em solo ou sobre rochas, especialmente em áreas montanhosas e de clima temperado (Kramer et al. 1990).

1- Plantas hemiepífitas

\section{Chave para identificação das espécies}

2- Caule com escamas rígidas, castanho escuras; primeira pínula próxima à raque saindo em direção a porção basal da fronde (catadrômica) 18. Polybotrya cylindrica

2'- Caule com escamas macias, castanho claras ou castanho avermelhadas; primeira pínula próxima a raque saindo em direção a porção apical da fronde (anadrômica)

3- Caule com escamas castanho avermelhadas; lâmina 1-2-pinado-pinatífida; segmentos com margem crenada a serreada 19. Polybotrya semipinnata 3'- Caule com escamas castanho claras; lâmina 3-pinado-pinatífida até próximo ao ápice; segmentos com margem inteira 20. Polybotrya speciosa

1'-Plantas terrícolas, rupícolas ou saxícolas

4- Venação areolada 22. Tectaria incisa

4'-Venação livre

5- Frondes férteis e estéreis dimorfas

17. Olfersia cervina

5'- Frondes férteis e estéreis monomorfas

6- Soros lineares ou ligeiramente falciformes, margeando um ou dois lados das nervuras 7- Lâmina 3-4 pinado-pinatífida

8-Caule ereto, subarborescente 6. Diplazium ambiguum

8 '- Caule reptante, nunca subarborescente 9. Diplazium herbaceum 7'-Lâmina simplesmente pinada ou pinado-pinatífifida 
9- Lâmina pinada; segmentos com margem inteira 7. Diplazium celtidifolium

9'-Lâmina pinado-pinatífida; segmentos com margem crenada ou serreada

10- Caule ereto; lâmina glabra 8. Diplazium cristatum

10'- Caule reptante; lâmina pubescente nas duas faces 10. Diplazium petersenii 6'- Soros arredondados ou elípticos, sobre as nervuras

11- Lâmina 2-pinada; segmentos dimidiados; soros elípticos

5. Didymochlaena truncatula

11'-Lâmina 1, 2 ou 3-4-pinado-pinatífida; segmentos nunca dimidiados; soros arredondados

12- Lâmina 3-4 pinado-pinatífida; raque geralmente com gema prolífera no ápice.

11. Lastreopsis effusa

12'-Lâmina 1 ou 2-pinado-pinatífida; raque sem gema prolífera no ápice

13- Nervuras basais do lado basiscópico dos segmentos partindo da costa

12. Megalastrum grande

13'- Nervuras basais do lado basiscópico dos segmentos partindo da cóstula

14- Pinas com base decurrente; segmentos com margens fortemente crenadas ou serreadas; nervuras com extremidade clavada, não atingindo a margem 13. Stigmatopteris caudata

14'-Pinas com base não decurrente; segmentos com margens inteiras ou levemente crenadas; nervuras com terminação não clavada, atingindo a margem

15- Raque e costa densamente cobertas por escamas não clatradas, castanho claras ou alvacentas 2. Ctenitis deflexa

15'- Raque e costa esparsamente cobertas por escamas clatradas

16- Base do estípite coberto por escamas castanho claras, soros submarginais

4. Ctenitis submarginalis

16'-Base do estípite coberto por escamas castanho escuras, soros medianos

17- Escamas da costa lineares, com células alongadas, margem denteada

3. Ctenitis falciculata

17'- Escamas da costa ovado-acuminadas, com células arredondadas, margem inteira 1. Ctenitis aspidioides

1. Ctenitis aspidioides (C. Presl) Copel., Gen. Fil. 124. 1947.

Planta terrícola, ocorre em locais sombreados ou parcialmente sombreados no sub-bosque, entre 200 e $300 \mathrm{~m}$ alt.

Material examinado: trilha do Cambucá, 19.X.1996, Bovini 1088; trilha da Toca da Aranha, 29.IX.1998, Mynssen 230.

2. Ctenitis deflexa (Kaulf.) Copel., Gen. Fil. 124. 1947.

Planta terrícola, ocorre em locais sombreados e úmidos, às margens de curso d'água ou não, substrato com grande quantidade de matéria orgânica, entre cerca de 150 e $250 \mathrm{~m}$ alt. Material examinado: trilha do Cabucá, 19.X.1996, Braga 3606; trilha da Lagoa Se- ca, 13.VIII.1999, Mynssen 284; margem direita do rio Grande, a partir da trilha do Corisquinho, 20.I.2000, Nonato 687, 688.

\section{Ctenitis falciculata (Raddi) Ching,} Sunyatsenia 5:250. 1940.

Planta terrícola, ocorre no sub-bosque em áreas parcialmente sombreadas, a cerca de $200 \mathrm{~m}$ alt. É uma espécie semelhante a C. aspidioides distinta por apresentar escamas da costa lineares, com células alongadas e margens denteadas.

Material examinado: trilha do Corisquinho, 3.VI.1997, Mynssen 131. 
4. Ctenitis submarginalis (Langsd. et Fisch.) Ching, Sunyatsenia 5(4): 250. 1940.

Planta terrícola, ocorre isoladamente às margens das trilhas ou no sub-bosque, em ambientes sombreados ou mais expostos a luz solar, ocorre freqüentemente entre 150 e 400 $\mathrm{m}$ alt.

Material examinado: trilha do Cambucá e Borboletas, 14.X.1996, Lira Neto 401; id., 30.XI.1996, Sylvestre 1241; trilha da Toca da Aranha, 22.X.1997, Mynssen 156; id., 26.VIII.1998, Santos 1062; trilha do Tião, 6.I.2000, Mynssen 300.

5. Didymochlaena truncatula (Sw.) J. Sm., J. Bot. (Hooker) 4: 196. 1842.

Planta terrícola, ocorre com pouca frequência no sub-bosque e às margens da trilha, entre 300 e $600 \mathrm{~m}$ alt.

Material examinado: trilha do Corisco, 21.I.2000, Santos 1381; trilha da Lagoa Seca, 26.V.1998, Mynssen 190.

6. Diplazium ambiguum Raddi, Opusc. Sci. 3:292. 1819.

Planta terrícola, geralmente ocupa ambientes muito úmidos às margens de rios ou próxima de pequenos cursos d'água, no interior da mata onde predomina a sombra, é freqüente entre 100 e $600 \mathrm{~m}$ alt.

Material examinado: trilha do Cambucá, 17.VIII.1996, Bovini 1017; id., 30.XI.1996, Sylvestre 1222; id., 6.V.1997, Mynssen 92, 99; trilha do Corisco, 6.I.2000, Mynssen 305; trilha do Corisquinho, 15.IX.1996, Braga 3506; trilha da Lagoa Seca, 27.VIII.1998, Mynssen 224.

7. Diplazium celtidifolium Kunze, Bot. Zeitung (Berlin) 3(17): 285. 1845.

Planta terrícola, habitando sempre locais sombreados com dossel fechado e vegetação densa. Formam populações abundantes e exuberantes entre 480 e $600 \mathrm{~m}$ alt.

Material examinado: trilha do Corisco, 21.I.2000, Santos 1378; trilha da Lagoa Seca, 26.V.1998, Mynssen 185.
8. Diplazium cristatum (Desr.) Alston, J. Bot. 74: 173.1936.

Ocorre como terrícola, sobre rochas ou entre suas fendas, geralmente está associada a ambientes úmidos e sombreados às margens de rio e córregos onde é freqüente, principalmente entre 100 e $500 \mathrm{~m}$ alt.

Material examinado: trilha do Cambucá, 30.XI.1996, Sylvestre 1262; id., 6.V.1997, Mynssen 106; id., 27.VIII.1998, Mynssen 207; trilha do Corisquinho, 26/04/1997, Braga 3964; id., 3.VI.1997, Mynssen 132; trilha da Toca da Aranha, 22.X.1997, Mynssen 157; id., 26.VIII.1998, Nonato 538; trilha da Lagoa Seca, 26.V.1998, Mynssen 164, 172, 186.

9. Diplazium herbaceum Fée, Crypt. Vasc. Brésil 1: 80, t. 23, f. 1. 1869.

Planta terrícola, habita locais parcialmente sombreados e úmidos ou secos e expostos ao sol. Foram observados indivíduos isolados no sub-bosque ou às margens das trilhas, entre 300 e $450 \mathrm{~m}$ alt.

Material examinado: trilha do Corisco, 6.I.2000, Mynssen 304; trilha do Corisquinho, 3.VI.1997, Mynssen 136.

10. Diplazium petersenii (Kunze) Christ, Bull. Acad. Int. Géogr. Bot. 11(153-154): 245. 1902.

Planta preferencialmente terrícola, podendo ocorrer como saxícola em ambientes sombreados e úmidos ou mais expostos ao sol, comumente observada entre 100 e $400 \mathrm{~m}$ alt. A lâmina de Diplazium petersenii é similar a de $D$. cristatum, mas pode ser facilmente distinguida no campo por seu caule reptante e pela lâmina finamente membranácea com tricomas brilhantes na face abaxial. Segundo Cislinski (1996), D. petersenii é uma espécie asiática que foi introduzia no Brasil e cresce de forma subespontânea.

Material examinado: trilha do Corisquinho, 1.XII.1996, Braga 3678; id., 6.V.1997, Mynssen 113; id., 3.VI.1997, Mynssen 120, 121; trilha da Lagoa Seca, 26.V.1998, Mynssen 165. 
11. Lastreopsis effusa (Sw.) Tindale, Victoria Naturalist 73: 184. 1957.

Planta terrícola, formando densas populações às margens das trilhas, em áreas parcialmente sombreadas, entre 200 e $300 \mathrm{~m}$ alt. Sua raque possui, freqüentemente, gema prolífera no ápice da fronde.

Material examinado: trilha do Cambucá, 30.XI.1996, Sylvestre 1226; trilha da Lagoa Seca, 26.V.1998, Mynssen 176, 182, 184; trilha da Toca da Aranha, 22.X.1997, Mynssen 154; 4.XI.1997, Braga 4437.

12. Megalastrum grande (C. Presl) A. R. Sm. et R. C. Moran, Amer. Fern J. 77 (4): 127. 1987.

Planta terrícola, ocorre em locais parcialmente sombreados às margens das trilhas em solo argiloso próxima a córregos ou não. Foi observada entre 250 e 600 m alt., sendo mais freqüente nos arrredores da trilha da Lagoa Seca. De acordo com os caracteres diagnósticos propostos por Smith \& Moran (1987), o gênero Megalastrum pode ser distinguido no campo de Ctenitis pela primeira veia do lado basiscópico dos segmentos partindo da costa e não da cóstula.

Material examinado: trilha da Lagoa Seca, 27.V.1997, Lira Neto 561; id., 26.V.1998, Mynssen 175, 177; id., 13.VIII.1999, Mynssen 287.

13. Olfersia cervina (L.) Kunze, Flora 7: 312. 1824.

Planta preferencialmente terrícola, podendo ocasionalmente ocorrer como epífita mas, neste caso, sobre o forófito até cerca de $1 \mathrm{~m}$ do solo. Está sempre associada a ambientes úmidos e sombreados e é mais freqüente acima de $300 \mathrm{~m}$ alt., tendo sido observada até $600 \mathrm{~m}$ alt.

Material examinado: trilha do Cambucá e rio Grande, 19.X.1996, Lira Neto 449; trilha do Cambucá, 30.XI.1996, Sylvestre 1221; trilha do Corisco, 21.I.2000, Nonato 702; trilha da Toca da Aranha, 21.X.1997, Braga 4364.
14. Polybotrya cylindrica Kaulf., Enum. Filic. 56. 1824.

Trata-se de uma espécie hemiepífita, que ocorre em áreas parcialmente sombreadas no sub-bosque, entre 70 e $300 \mathrm{~m}$ alt. É endêmica do sudeste e sul do Brasil, diferenciando-se das outras espécies pelas escamas com base espessa e encurvada (Moran 1987).

Material examinado: trilha das Borboletas, 1.XII.1996, Braga 3689; trilha do Corisco, 21.I.2000, Santos 1377; trilha do Poço do Cambucá, 26.VIII.1998, Santos 1069.

15. Polybotrya semipinnata Fée, Crypt. Vasc. Brésil 1: 16. 1869.

Planta hemiepífita, pouco freqüente, ocorre em local extremamente sombreado e úmido a cercade $400 \mathrm{~m}$ alt. Segundo Moran (1987), a espécie é endêmica da Serra do Mar, da Região Sudeste e Sul do Brasil. A lâmina é menos segmentada se comparada as demais espécies de Polybotrya. Material examinado: trilha da Toca da Aranha, 11.I.1999, Mynssen 247.

16. Polybotrya speciosa Schott, Gen. Fil. tab. 7. 1834.

Planta hemiepífita, de local bastante sombreado, a cerca de $600 \mathrm{~m}$ alt.

Material examinado: trilha do Corisco, 21.I.2000, Mynssen 328.

17. Stigmatopteris caudata (Raddi) C. Chr., Bot. Tidsskr. 29: 302.1909.

Planta terrícola, de ambiente sombreado, podendo ocorrer próxima de cursos d'água ou não, entre 200 e $680 \mathrm{~m}$ alt. Moran (1991) trata esta espécie como endêmica do sudeste e sul do Brasil, distinta pelas pinas com lobos basiscópicos adnatos a raque e margens serreadas. Este gênero possui a morfologia da lâmina semelhante à de Ctenitis, mas pode ser facilmente distinguido deste no campo pelos segmentos fortemente serreados e veias com terminação clavada.

Material examinado: trilha do Corisco, 21.I.2000, Nonato 703; trilha da Lagoa Seca, 26.VIII. 1998, Nonato 542; id., 13.VIII.1999, Mynssen 285; trilha da Toca da Aranha, 11.I.1999, Mynssen 250. 
18. Tectaria incisa Cav., Descr. P1. 249. 1802.

Planta terrícola, ocorre em áreas parcialmente sombreadas às margens das trilhas ou no sub-bosque. Verifica-se nas populações que os espécimes muito jovens possuem a lâmina membranácea e pilosa, com aspecto áspero. É observada entre a faixa de 100 e $680 \mathrm{~m}$ alt., mas é bastante freqüente até $400 \mathrm{~m}$.

Material examinado: trilha do Cambucá, 30.XI. 1996, Bovini 1087; id., 30.XI.1996, Sylvestre 1247; id., 6.V.1997, Mynssen 108; trilha do Mirante, 3.VI.1997, Mynssen 118; trilha da Toca da Aranha, 29.IX.1998, Mynssen 229.

Referências: Brade 1971, 1972; Sehnem 1979 a; Cislinki, 1986; Smith \& Moran 1987; Moran 1987, 1991; Tryon \& Stolze 1991.

\section{Gleicheniaceae}

A maior parte das espécies da família Geicheniaceae ocorre em áreas abertas, muito perturbadas ou pioneiras e três dos quatro gêneros desta família são pantropicais, somente Gleichenia s. st. está restrito ao Velho Mundo (Kramer 1990a).
1. Dicranopteris pectinata (Willd.) Underw., Bull. Torrey Bot. Club 34 (5): 260. 1907.

Planta terrícola, ocorre em barrancos argilosos às margens das trilhas, sempre nas áreas mais abertas e ensolaradas, entre 70 e $150 \mathrm{~m}$ alt. Freqüentemente verifica-se sua população crescendo e apoiando-se nas plantas adjacentes. A fronde pseudo-dicotomicamente dividida, sem pinas acessórias reflexas e a ramificação desigual dos ramos caracterizam bem esta espécie.

Material examinado: trilha das Borboletas, 6.V.1997, Mynssen 116; trilha do Mirante, 26.VIII.1998, Santos 1066.

Referências: Sehnem 1970 a; Windisch 1994; Andersen \& Øllgaard 1996.

\section{Hymenophyllaceae}

A família Hymenophyllaceae possuiu ampla distribuição nas regiões tropical e temperada úmida (Tryon \& Tryon 1982). Segundo Windisch (1996), é constituída por 550 a 600 espécies e, embora sua classificação ainda não esteja completamente esclarecida, são reconhecidos dois gêneros: Trichomanes e Hymenophyllum.

\section{Chave para identificação das espécies}

1- Indúsio bivalvar, nunca tubular, valvas constituindo a maior parte do indúsio

1. Hymenophyllum fragile ( $H$. fragile var. venustum)

1'-Indúsio tubular, obcônico ou infundibuliforme, às vezes bilabiado com as valvas constituindo a menor parte do indúsio

2- Plantas adultas maiores do que $10 \mathrm{~cm}$ de compr.

3- Estípites com 1-2cm compr., lâmina 2-3-pinado pinatífida ....... 7. Trichomanes radicans

3'-Estípites com 0,1-0,5cm compr., lâmina pinado pinatífida 8. Trichomanes rupestre

2'- Plantas adultas menores do que $10 \mathrm{~cm}$ de compr.

4- Lâmina com pêlos estrelados, negros, marginais

5- Lâmina inteira ou lobada

3. Trichomanes angustifrons

5'-Lâmina pinatífida

6- Soros situados na porção apical da lâmina, indúsio não imerso no tecido laminar ou imerso somente na porção basal

4. Trichomanes hymenoides

6'-Soros situados tanto nos segmentos laterais quanto nos apicais, indúsio totalmente imerso no tecido laminar 5. Trichomanes krausii

4'- Lâminas com pêlos simples, castanhos, sobre a face abaxial das nervuras

7- Raque alada, soros imersos no tecido laminar 6. Trichomanes pyxidiferum

7'-Raque não alada, soros não imersos no tecido laminar, ou imersos somente na porção basal 
1. Hymenophyllum fragile var. venustum (Desv.) C. V. Morton, Contr. U.S. Natl. Herb. 29(3): 173.1947.

Planta epífita, recobrindo densamente o forófito, juntamente com outras epífitas, em ambiente muito sombreado no interior da mata, observada a cerca de $800 \mathrm{~m}$ alt.

Material examinado: trilha da Lagoa Seca, 13.VIII.1999, Mynssen 288.

2. Trichomanes angustatum Carmich., Trans. Linn. Soc. London 12: 513. 1818.

Planta preferencialmente epífita, mas pode ocorrer como rupícola, em ambiente muito sombreado, na mata densa às margens do rio entre 400 a $450 \mathrm{~m}$ alt., foi freqüentemente observada sobre Cyatheaceae.

Material examinado: margem do Rio Grande, proximidades da trilha do Cambucá, 17.VIII.1996, Braga 3431; trilha da Cachoeira após a entrada do Corisco, 21.I.2000, Santos 1389.

3. Trichomanes angustifrons (Fée) Wess. Boer, Fl. Neth. Antill. 1(Pterid.): 17. 1962.

Planta epífita ou rupícola sobre rochas com grande camada de húmus, sempre em ambientes muito sombrios e úmidos, podendo estar próxima de cursos d'água ou não, entre 200 e 300 m alt.

Material examinado: trilha da Lagoa Seca, 27.VIII.1998, Mynssen 209; Poço do Cambucá, 27.VIII.1998, Mynssen 216.

4. Trichomanes hymenoides Hedw., Fil. Gen. Sp. t. 3, f. 3. 1799.

Planta rupícola, ocorrendo no interior da mata densa ou às margens de rios, em ambientes úmidos com muita sombra, de 100 a $300 \mathrm{~m}$ alt.

Material examinado: trilha do Corisquinho, proximidades da margem do rio Grande, 15.IX.1996, Braga 3504; triha da Lagoa Seca, 26.V.1998, Mynssen 192; id., 27.VIII.1998, Mynssen 210; trilha da Toca da Aranha, 11.I.1999, Mynssen 244.
5. Trichomanes krausii Hook. et Grev., Ic. Filic. 2: t. 149. 1830.

Planta preferencialmente rupícola sempre encontrada em áreas sombreadas e úmidas, observada entre 70 e $450 \mathrm{~m}$ alt. Geralmente observa-se uma projeção laminar nos enseio, em forma de dente com tricomas estrelados negros. Esta característica auxilia na separação de Trichomanes hymenoides, que não tem esta projeção no enseio.

Material examinado: margem do rio Grande 20.I.2000, Nonato 681, 693; trilha do Cambucá, 30.XI.1996, Sylvestre 1234; id., 27.VIII.1998, Mynssen 217 A; trilha do Corisco, 6.I.2000, Mynssen 311; trilha do Corisquinho, 1.XII.1996, Braga 3677; id., 3.VI.1997, Mynssen 133; trilha da Lagoa Seca, 13.VIII.1999, Mynssen 290, 291.

6. Trichomanes pyxidiferum L., Sp. Pl. 2: 1098. 1753.

Planta rupícola, formando populações que recobrem afloramentos rochosos, em ambientes úmidos e sombreados no interior da mata, entre 100 a $400 \mathrm{~m}$ alt. Pode ocorrer simultaneamente com Trichomanes krausii. Material examinado: margem do rio Grande, 20.I.2000, Nonato 694; Poço do Cambucá, 27.VIII.1998, Mynssen 214; id., 29.IX.1998, Mynssen 239; trilha do Cambucá, 27.VIII.1998, Mynssen 217B; trilha da Toca da Aranha, 21.X. 1997, Braga 4347; id., 11.I.1999, Mynssen 245.

7. Trichomanes radicans Sw., J. Bot. (Schrader) 1800 (2): 97. 1801.

Planta preferencialmente epífita, mas também pode ocorrer como rupícola, sempre em mata densa e sombreada, entre 200 e 800 $m$ alt.

Material examinado: trilha do Corisco, 21.I.2000, Santos 1379; trilha do Corisco depois da cachoeira, 21.I.2000, Nonato 700; trilha da Lagoa Seca, 27.V.1997, Lira Neto 565; id., 13.VIII.1999, Mynssen 283; trilha da Toca da Aranha, 26.VIII.1998, Mynssen 205; id., 11.I.1999, Mynssen 242, 255. 
8. Trichomanes rupestre (Raddi) Bosch, Ned. Kruidk. Arch. 4: 370.1859 [1858].

Planta rupícola, sobre pedras em áreas úmidas e sombreadas, próximas de cursos d'água ou não, entre 200 e $500 \mathrm{~m}$ alt. Nunca foi coletada fértil na Reserva Rio das Pedras. É semelhante a Trichomanes radicans, porém a lâmina é menos segmentada e os segmentos são mais largos e membranáceos.

Material examinado: trilha da Lagoa Seca, 26.V.1998, Mynssen 189; id., 26.VIII.1998, Santos 1058; id., 29.IX.1998, Mynssen 238; id., 11.I.1999, Mynssen 243, 254; trilha da Toca da Aranha, 21.X.1997, Braga 4365.
Referências: Boer 1962; Sehnem 1971; Tryon \& Tryon 1982; Mickel \& Beitel 1988; Windisch 1992 b, 1996.

\section{Lomariopsidaceae}

A família Lomariopsidaceae possui distribuição pantropical com concentração de espécies no Neotrópico. Segundo Kramer (1990b), muitos autores acreditam que esta família está restritamente relacionada com Dryopteridaceae, sendo incluída por alguns como sub-família ou tribo desta (i.e.Tryon \& Tryon 1982).

\section{Chave para identificação das espécies}

1 - Planta epífita; lâmina simples; estípites com base articulada ...... 2.Elaphoglossum scolopendrifolium 1'-Planta terrícola ou hemiepífita; lâmina pinada; estípites com base não articulada

2- Nervuras livres 4. Lomariopsis marginata

2'- Nervuras areoladas

3- Planta terrícola; pinas não articuladas 1. Bolbitis serratifolia 3'- Planta hemiepífita; pinas articuladas 3. Lomagramma guianensis

1. Bolbitis serratifolia (Kaulf.) Schott, Gen. Fil. t. 13. 1834.

Planta terrícola, ocorre em locais muito sombreados e úmidos, geralmente próxima de cursos d'água, sendo freqüente entre 70 e 400 m alt.

Material examinado: trilha do Cambucá, 30.XI.1996, Sylvestre 1225; trilha da Lagoa Seca, 27.V.1997, Lira Neto 569; id., 26.V.1998, Mynssen 173; trilha da Toca da Aranha, 29.IX.1998, Mynssen 236.

\section{Elaphoglossum scolopendrifolium (Raddi)}

J. Sm., Bot. Mag. Suppl. 17. 1846.

Planta epífita, eventualmente encontrada como rupícola em rochas cobertas por húmus, em locais muito úmidos e sombreados, às margens do rio ou não. Em geral, formam densas populações, com indivíduos muito jovens até adultos, de aproximadamente 300 até 500 m alt.

Material examinado: trilha da Toca da Aranha, 11.I.1999, Mynssen 252.
3. Lomagramma guianensis (Aubl.) Ching, Amer. Fern J. 22: 17. 1932.

Planta hemiepífita, ocorre em áreas sombreadas nas adjacências das trilhas e foi observada com maior freqüência de 300 até $600 \mathrm{~m}$ alt.

Material examinado: trilha do Corisco, 21.I.2000, Santos 1375; trilha da Lagoa Seca, 27.VIII.1998, Mynssen 218; trilha da Toca da Aranha, 29.IX.1998, Mynssen 233.

4. Lomariopsis marginata (Schrad.) Kuhn, Reis Ost-Afr. Bot. 3(3): 22.1879.

Planta hemiepífita, ocorre em local úmido e de sombra intensa, a cerca de $400 \mathrm{~m}$ alt. Segundo Moran (2000), Lomariopsis marginata pode ser distinta das outras espécies americanas pelas escamas castanho avermelhadas do caule e pelo grande número de pinas (1020 pares), asseme-lha-se a L. japurensis (Mart.) J. Sm., sendo que esta possui as escamas do caule escuras e mais estreitas, nunca com uma cor clara e brilhante como em $L$. marginata. Ainda segundo este autor, $L$. 
marginata é a única espécie do gênero que ocorre na região litorânea do Brasil.

Material examinado: trilha da Toca da Aranha, 11.I.1999, Mynssen 246.

Referências: Alston 1958; Brade 1960-61; Moran 2000.

\section{Lycopodiaceae}

A família Lycopodiaceae é constituída por quatro gêneros e, excetuando-se Phylloglossum que ocorre somente na Austrália, todos os outros são cosmopolitas, com a maior concentração de espécies nas regiões úmidas e montanhosas tropicais (Øllgaard 1990).

1. Lycopodiella cernua (L.) Pic. Serm., Webbia 23 (1): 166. 1968.

Planta terrícola, ocorre em áreas muito ensolaradas, às margens da trilha, de 70 a 150 $\mathrm{m}$ alt. Segundo Øllgaard \& Windisch (1987), tratase de uma espécie pantropical, pioneira e comum em áreas de solo perturbado ao longo de caminhos, rios e clareiras em florestas.

Material examinado: trilha do Mirante, 17.VIII.1996, Braga 3045; trilha da Toca da Aranha, 11.I.1999, Mynssen 240.

Referências: Øllgaard \& Windisch 1987; Øllgaard 1990.

\section{Marattiaceae}

A família Marattiaceae ocorre em florestas úmidas primárias e secundárias nas regiões tropicais e sub-tropicais. É constituída por cerca de 100 espécies e quatro gêneros, dos quais Danaea e Marattia são os únicos que ocorrem no continente americano, sendo o primeiro exclusivamente neotropical (Camus 1990).

1. Danaea elliptica Sm., Cycl. 11: Danaea no. 2. 1808 .

Planta terrícola, ocorre em locais totalmente sombreados e úmidos, cujos indivíduos jovens são encontrados freqüentemente crescendo sobre rochas úmidas cobertas por húmus, próximas de barrancos argilosos, entre 250 e $600 \mathrm{~m}$ alt. A forma dos segmentos e a presença de nós no estípite são os principais caracteres que separam esta espécie de Danaea nodosa (L.) J. Sm.

Material examinado: trilha da Lagoa Seca, 27.VIII.1998, Mynssen 225; trilha da Toca da Aranha, 11.I.1999, Mynssen 251.

Referências: Sehnem 1967 b; Camus 1990; Pérez-Garcia 1993; Windisch 1995.

\section{Nephrolepidaceae}

A família Nephrolepidaceae é constituída por um único gênero Nephrolepis com cerca de 30 espécies, com a maior concentração de espécies no sudeste da Ásia, sendo muitas espécies introduzidas em novas áreas pelo cultivo. Geralmente Nephrolepis é tratado dentro da família Davalliaceae, mas os caracteres anatômicos e dos esporos são tão divergentes que justifica ser tratado em uma família distinta (Kramer 1990c).

\section{Chave para identificação das espécies}

1- Planta terrícola; soros com indúsio orbicular

1. Nephrolepis multiflora

1'- Planta rupícola; soros com indúsio reniforme

2. Nephrolepis pectinata

1. Nephrolepis multiflora (Roxb.) C. V. Morton, Contr. U.S. Natl. Herb. 38(7): 309. 1974.

Planta terrícola, em regiões mais degradadas e muito expostas ao sol, em grandes populações, a cerca de $150 \mathrm{~m}$ alt. As espécies do gênero Nephrolepis são muito cultivadas e usa- das em ornamentação. Segundo Tryon \& Tryon (1982), são ecologicamente adaptadas e crescem em uma grande variedade de hábitats. Material examinado: trilha das Borboletas, 3.VI.1997, Mynssen 117. 
2. Nephrolepis pectinata (Willd.) Schott, Gen. Fil. pl. 3. 1834.

Planta rupícola, heliófila, coberta por vegetação graminóide, próxima ao cume do morro Corrisco a cerca de $1.030 \mathrm{~m}$ alt.

Material examinado: trilha do Corisco, 18.I.2001, Braga 6631.

Referências: Morton 1958; Tryon 1964;

Sehnem 1979b; Tryon \& Tryon 1982; Kramer 1990c.

\section{Polypodiaceae}

A família Polypodiaceae possui uma ampla distribuição, sendo constituída por 1.000 ou mais espécies quase todas epífitas, distribuídas em aproximadamente 40 gêneros, dos quais 12 estão representados nas Américas (Tryon \& Tryon 1982).

\section{Chave para identificação das espécies}

1- Lâmina pinada, pinatífida ou pinatisecta

2- Lâmina com venação areolada

3- Lâmina pinada

4- Pinas oblongo-acuminadas, curtamente estipitadas ou adnatas com bases decurrentes; nervura proeminente nas duas faces

5- Pinas com 5-8 aréolas entre a costa e a margem, 2-3 nervuras livres em cada aréola

1. Campyloneurum decurrens

5'-Pinas com 3-4 aréolas entre a costa e a margem, uma nervura livre em cada aréola

19. Polypodium triseriale

4'-Pinas lanceoladas a oblongo-acuminadas, adnatas com bases não decurrentes; nervura não proeminente nas duas faces 15. Polypodium fraxinifolium

3'-Lâmina pinatífida ou pinatissecta

6- Estípite e lâmina densamente cobertos por escamas

7- Plantas com 20-40 cm de altura; com 5-9 pinas basais reduzidas

16. Polypodium hirsutissimum

7'- Plantas com 3-6 cm de altura; pinas basais não reduzidas

18. Polypodium polypodioides

6'-Estípite e lâmina glabros ou cobertos por escamas esparsas

8- Lâmina com escamas conspícuas, peltadas, venação não evidente

8'-Lâmina glabra, venação evidente

11. Pleopeltis angusta

9- Lâmina com 9-22 pares de segmentos; segmentos basais levemente deflexos; escamas do caule longamente acuminadas 14. Polypodium catharinae

9'-Lâmina com 24-36 pares de segmentos, segmentos basais não deflexos; escamas do caule curtamente acuminadas 17. Polypodium latipes

2'- Lâmina com venação livre

10- Segmentos com ápices acuminados, nervuras 3-4 vezes furcadas

8. Pecluma paradiseae

10'-Segmentos com ápices obtusos, nervuras simples ou uma vez furcada 11- Segmentos deflexos, raque com escamas filiformes ......... 9. Pecluma pectinatiformis
11 '- Segmentos não deflexos, raque com escamas triagulares acuminadas ..................

10. Pecluma plumula

1'-Lâmina simples

12- Soros dispostos em duas séries entre a costa e a margem 
13- Lâmina brilhante nas duas faces, venação imersa 4. Campyloneurum rigidum

13'- Lâmina fosca nas duas faces, venação proeminente

14- Nervura secundária sinuosa, 5-6 aréolas entre a costa e a margem

2. Campyloneurum minus

14'-Nervura secundária retilínea, 7-9 aréolas entre a costa e a margem

3. Campyloneurum nitidum

12'- Soros dispostos em uma série entre a costa e a margem

15- Frondes dimorfas

16- Lâmina densamente coberta por escamas ovadas a oblongo-ovadas, longo acuminadas, no tecido laminar e nervuras

6. Microgramma tecta

16'- Lâmina esparsamente coberta por escamas filiformes, na face abaxial da costa e nas margens

7. Microgramma vacciniifolia

15'-Frondes monomorfas

17- Lâmina sem escamas

5. Microgramma geminata

17'- Lâmina com de escamas

18- Estípites curtos (1-2 cm compr.), soros alongados a elípticos .

18'-Estípites longos (3-10 cm compr.), soros arredondados

12. Pleopeltis astrolepis

13. Pleopeltis percussa

1. Campyloneurum decurrens (Raddi) C. Presl, Tent. Pterid. 190. 1836.

Planta rupícola ou saxícola, em ambientes muito sombreados e úmidos no leito dos rios, entre 150 e $600 \mathrm{~m}$ alt. Diferencia-se das outras espécies do gênero por apresentar lâmina pinada.

Material examinado: trilha do Cambucá, 30.XI.1996, Sylvestre 1259; id., 22.III.1999, Mynssen 260; trilha da Lagoa Seca, 26.V.1998, Mynssen 187.

2. Campyloneurum minus Fée, Gen. Fil. [Mém. Foug. 5] 258. 1852.

Planta epífita de ambientes muito sombreados e úmidos, ocorre em áreas onde a mata encontra-se mais preservada e o dossel é fechado, apresentando diversas epífitas, de 500 a $600 \mathrm{~m}$ alt. Nos herbários é freqüentemente identificada como Campyloneurum herbaceum (Christ) Ching ou Campyloneurum lapathifolium (Poir.) Ching. León (1992) considerou $C$. herbaceum como sinônimo de $C$. minus e C. lapathifolium como sinônimo de C. repens.

Material examinado: trilha do Corisco, 21.I.2000, Mynssen 323, Santos 1376.
3. Campyloneurum nitidum (Kaulf.) C. Presl, Tent. Pterid. 190. 1836.

Planta preferencialmente rupícola ou saxícola. Habita locais sombreados e úmidos, é freqüente às margens dos rios, entre $100 \mathrm{e}$ $600 \mathrm{~m}$ alt. Esta espécie é freqüentemente confundida com Campyloneurum phyllitidis (L.) C. Presl. Segundo León (1992), apesar de pertencer ao mesmo grupo, C. nitidum tem dimensões menores e escamas ovadas com ápices obtusos.

Material examinado: trilha do Cambucá e Rio Grande, 18.VIII.1996, Lira Neto 330; trilha do Cambucá, 30.XI.1996, Sylvestre 1240; id., 6.V.1997, Mynssen 107; id., 26.VIII.1998, Dória 2; trilha da Lagoa Seca, 12.VII.1997, Braga 4219; id., 27.VIII.1998, Mynssen 219, 211; trilha da Toca da Aranha, 22.X.1997, Mynssen 152; id., 26.VIII.1998, Mynssen 199.

\section{Campyloneurum rigidum J. Sm., Cat. Kew} Ferns 2. 1856.

Planta preferencialmente rupícola, ocasionalmente terrícola, ocorrendo sempre em regiões muito sombreadas e úmidas. Foi localizada entre 250 e $500 \mathrm{~m}$ alt. 
Material examinado: trilha da Toca da Aranha, 4.XI.1997, Andreata 1032; id. 26.VIII.1998, Mynssen 196, Santos 1059; id., 29.IX.1998, Mynssen 235.

5. Microgramma geminata (Schrad.) R. M. Tryon \& A. F. Tryon, Rhodora 84: 129. 1982.

Planta epífita, abundante às margens do rio Grande, especialmente nas proximidades da localidade de Lages. Habita áreas parcialmente sombreadas a cerca de $150 \mathrm{~m}$ alt.

Material examinado: margem do rio Grande, proximidades de Lages, 20.I.2000, Santos 1374.

6. Microgramma tecta (Kaulf.) Alston, J. Wash. Acad. Sci. 48: 232. 1958.

Planta preferencialmente epífita, ocasionalmente rupícola. Habita áreas úmidas e sombreadas até secas e mais expostas ao sol, entre 100 e $600 \mathrm{~m}$ alt.

Material examinado: margem do rio Grande, proximidades da trilha do Cambucá, 17.VIII.1996, Braga 3428; trilha do Corisco, 21.I.2000, Santos 1386; trilha do Corisquinho, 1.XII.1996, Braga 3679; id., 3.VI.1997, Mynssen 141; trilha da Toca da Aranha, 22.X.1997, Mynssen 151.

7. Microgramma vacciniifolia (Langsd. et Fisch.) Copel., Gen. Fil. 185. 1947.

Planta epífita, pode ocorrer em ambientes mais expostos ao sol ou sombreados e não necessariamente úmidos, entre cerca de 100 e $450 \mathrm{~m}$ alt.

Material examinado: trilha do Cambucá, 17.VIII.1996, Braga 3419; id., 14.IX.1996, Bovini 1046; trilha do Corisquinho, 3.VI.1997, Mynssen 149.

8. Pecluma paradiseae (Langsd. et Fisch.) M. G. Price, Amer. Fern J. 73 (3): 115. 1983.

Planta terrícola, ocorre em ambientes sombreados e não necessariamente úmidos, entre 150 e $300 \mathrm{~m}$ alt.

Material examinado: trilha da Toca da Aranha, 26.VIII.1998, Mynssen 195, 198.
9. Pecluma pectinatiformis (Lindm.) M. G. Price, Amer. Fern J. 73(4): 115. 1983.

Planta epífita de ambientes sombreados e úmidos, pode ocorrer nas proximidades dos rios. Foi observada de 100 a $300 \mathrm{~m}$ alt.

Material examinado: Poço do Cambucá, 27.VIII.1998, Mynssen 215; trilha do Cambucá, 20.I.2000, Mynssen 314; trilha do Corisquinho, 6.V.1997, Mynssen 111.

10. Pecluma plumula (Willd.) M. G. Price, Amer. Fern J. 73(4): 115. 1983.

Planta preferencialmente epífita, mas pode ocorrer como rupícola em rochas com camada de húmus, em ambiente sombreado, próxima a cursos d'água ou não, entre $100 \mathrm{e}$ $500 \mathrm{~m}$ alt.

Material examinado: trilha do Cambucá, 14.IX.1996, Braga 3490; id., 30.XI.1996, Sylvestre 1264; id., 6.V.1997, Mynssen 95; trilha do Corisquinho, 6.V.1997, Mynssen 112; trilha da Toca da Aranha, 22.X.1997, Mynssen 150; id., 26.VIII.1998, Mynssen 200.

11. Pleopeltis angusta Humb. et Bonpl. ex Willd., Sp. P1. Ed. 4, 5: 211. 1810.

Planta epífita, ocorrendo eventualmente como rupícola em pedras revestidas por grande quantidade de húmus. Foi observada em ambientes mais abertos e expostos a luz solar, entre 100 e $300 \mathrm{~m}$ alt.

Material examinado: trilha do Cambucá, 14.IX.1996, Bovini 1039; id., 30.XI.1996, Sylvestre 1257; id., 6.V.1997, Mynssen 93; id., 22.III.1999, Mynssen 258; trilha da Toca da Aranha, 22.X.1997, Mynssen 159.

12. Pleopeltis astrolepis (Liebm.) E. Fourn., Mexic. P1. 1: 87. 1872.

Planta epífita crescendo ocasionalmente como rupícola sobre rochas com grande quantidade de húmus, em ambientes mais expostos a incidência solar, entre 70 e $300 \mathrm{~m}$ alt.

Material examinado: proximidades do rio Grande, 20.I.2000, Santos 1369; trilha do Cambucá, 30.XI.1996, Sylvestre 1258; id., 
6.V.1997, Mynssen 94; trilha do Mirante, 26.VIII.1998, Mynssen 204.

13. Pleopeltis percussa (Cav.) Hook. et Grev., Ic. Filic. 1: t. 67. 1828.

Planta epífita, ocorre em ambientes sombreados e úmidos, próxima ao curso do rio Grande. Foi observada entre 100 e $250 \mathrm{~m}$ alt. Material examinado: proximidades do rio Grande, 20.I.2000, Santos 1372; trilha do Cambucá e rio Grande, 18.VIII.1996, Lira Neto 331; id., 22.III.1999, Mynssen 257; trilha do Corisquinho, 6.V.1997, Mynssen 110; trilha da Lagoa Seca, 27.VIII.1998, Mynssen 220.

14. Polypodium catharinae Langsd.et Fisch., Pl. Voy. Russes Monde 1: 9, t. q. 1810.

Planta rupícola, em ambientes ensolarados e secos, entre 100 e $450 \mathrm{~m}$ alt. Esta espécie é semelhante a Polypodium latipes, mas pode ser diferenciada, além dos caracteres apresentados na chave, pelo caule menos robusto (6-10 mm diâm.) enquanto P. latipes possui caule com cerca de $15 \mathrm{~mm}$ diâm.

Material examinado: subindo o rio Grande a partir da trilha do Corisquinho, vegetação das pedras do meio do rio, 20.I.2000, Mynssen 321; trilha do Corisquinho, 3.VI.1997, Mynssen 144; trilha da Lagoa Seca, 27.VIII.1998, Mynssen 221.

\section{Polypodium fraxinifolium Jacq., Col-} lect. Bot. 3: 187. 1789 [1791].

Planta epífita que ocorre preferencialmente em locais sombreados e muito úmidos, às margens do rio Grande, entre $400 \mathrm{e}$ $500 \mathrm{~m}$ alt. Segundo Hensen (1990), esta espécie tem uma alta variabilidade na morfologia das escamas do rizoma, dos segmentos e esporos, o que tem gerado um grande número de sinônimos. De acordo com este autor, esta variação parece estar relacionada com as condições do hábitat.

Material examinado: trilha da Cachoeira após a entrada do Corisco, 21.I.2000, Santos 1391; id., 21.I.2000, Mynssen 327.
16. Polypodium hirsutissimum Raddi, Opusc. Sci. 3: 286. 1819.

Planta epífita, presente em áreas muito abertas e com grande incidência solar, entre 200 e $450 \mathrm{~m}$ alt. É caracterizada pela fronde densamente coberta por escamas castanhoavermelhadas, com margem fimbriada e hialina, o que deve favorecer seu estabelecimento nestes ambientes.

Material examinado: trilha do Cambucá 30.XI.1996, Sylvestre 1256; id., 6.V.1997, Mynssen 109; trilha do Corisquinho, 3.VI.1997, Mynssen 142, 148.

17. Polypodium latipes Langsd. et Fisch., Pl. Voy. Russes Monde 1: 10, t. 10. 1810.

Planta rupícola de ambiente seco e exposto ao sol. Foi observada a cerca de $450 \mathrm{~m}$ alt. Segundo Hensen (1990), esta espécie possui uma variação morfológica relacionada a distribuição geográfica, mas sua forma típica é encontrada no Brasil e Bolívia, caracterizando-se pelo caule espesso $(5-7 \mathrm{~mm})$, escamas fortemente clatradas e segmentos com duas séries de aréolas. Material examinado: trilha do Corisquinho, 3.VI.1997, Mynssen 140.

18. Polypodium polypodioides (L.) Watt, Canad. Naturalist \& Quart. J. Sci. ser. 2. 3: 158. 1867.

Planta rupícola, em rochas com grande camada de húmus, em ambientes aberto e ensolarado, a cerca de $400 \mathrm{~m}$ alt.

Material examinado: trilha da Cachoeira após a casa do Tião, 21.I.2000, Santos 1388.

19. Polypodium triseriale Sw., J. Bot. (Schrader) 1800 (2): 26. 1801.

Planta preferencialmente rupícola, podendo ocorrer como terrícola ou epífita, em locais parcialmente sombreados, entre 70 e 400 $\mathrm{m}$ alt. É uma espécie bastante comum nas diversas trilhas da RRP.

Material examinado: trilha do Cambucá, 30.XI.1996, Sylvestre 1261; id., 6.V.1997, Mynssen 115; trilha da Toca da Aranha, 26.VIII.1998, Mynssen 194. 
Referências: Sota 1965; Evans 1969; Sehnem 1970b; Price 1983; Hensen 1990; León 1992; Labiak \& Prado 1998.

\section{Pteridaceae}

A família Pteridaceae possui cerca de 33 gêneros e 750 espécies, amplamente distribuídas no mundo (Tryon \& Stolze 1989). Nas Américas ocorrem aproximadamente 22 gêneros (Tryon \& Tryon 1982).

1- Pínulas dimidiadas

\section{Chave para identificação das espécies}

2- Fronde formando conjunto de pinas radiadas

1. Adiantopsis radiata

2'-Fronde sem formar conjunto de pinas radiadas

3- Soros nas margens acroscópica e basiscópica das pínulas 3. Adiantum latifolium

3'- Soros somente na margem acroscópica das pínulas

4- Caule ereto ou decumbente, soros retilíneos e contínuos ..... 4.Adiantum pulverulentum

4'-Caule reptante, subterrâneo ou não, soros elípticos e descontínuos

5- Lâmina 2-pinada, pínulas com ápice obtuso, margem serreada simples

5. Adiantum serratodentatum

5'- Lâmina 3-4-pinada, pínulas com ápice longo acuminado ou agudo, margem crenado serreada

6- Pínulas com 2-4cm compr. e $0,7-1,0 \mathrm{~cm}$ larg.

2. Adiantum abscissum

6'- Pínulas com 4,5-7cm compr. e 1,5-2,0 cm larg.

6. Adiantum mynssenae

1'-Pínulas não dimidiadas

7- Lâmina pedata ou sagitada

8- Lâmina sagitada..

11. Doryopteris sagittifolia

8'- Lâmina pedada

9- Lâmina fértil com um lobo apical e dois lobos basais de cada lado.

9'-Lâmina fértil mais recortada e com mais lobos

9. Doryopteris lonchophora

10- Estípites com pelo menos uma face fortemente plana, castanhos, com escamas esparsas; soros marginais contínuos

8. Doryopteris collina

10'- Estípites cilíndricos ou levemente planos em uma face, castanho nigrescentes, densamente coberto por pêlos e escamas; soros marginais interrompidos nos enseio

10. Doryopteris pedata

7'-Lâmina 1-2-pinada ou 1-3-pinado pinatífida

11- Soros localizados na face abaxial da fronde

12- Lâmina pinada, coberta por pêlos alvos brilhantes nas duas faces, margens inteiras

12. Hemionitis tomentosa

12'- Lâmina 2-pinada, com indumento alvacento farináceo na face abaxial, margens serreadas 13. Pityrogramma calomelanos

11'-Soros localizados nas margens dos segmentos

14- Plantas adultas pequenas, com 3-5 cm de altura; soros reniformes

7. Cheilanthes incisa

14'- Plantas adultas grandes, com mais de $30 \mathrm{~cm}$ de altura; soros lineares

15- Segmentos com venação areolada somente junto a costa e cóstula, livres em direção à margem

16- Raque alada, segmento apical e lateral acuminado .... 20. Pteris leptophylla

16'-Raque não alada, segmento apical acuminado e laterais agudo ou obtuso ... 16. Pteris biaurita 
15'- Segmentos com venação totalmente areolada

17- Lâmina pinada 21. Pteris splendens

17'-Lâmina 1-3-pinado-pinatífida

18- Face adaxial das cóstulas com lacínios na base

14. Pteris altissima

18'- Face adaxial das cóstulas sem lacínios na base

19- Pinas todas pinatífidas

20- Pinas com 1-2 aréolas entre duas cóstulas adjacentes .... 18. Pteris decurrens

20'-Pinas com 3-7 aréolas entre duas cóstulas adjacentes .... 15. Pteris angustata

19'-Pinas apicais e medianas inteiras, as basais pinatífidas ou lobadas

21- Raque alada

19. Pteris denticulata

21'- Raque não alada

17. Pteris brasiliensis

1. Adiantopsis radiata (L.) Fée, Gen. Filic. [Mém. Foug. 5] 145. 1852.

Planta terrícola, ocorre em ambientes mais secos e expostos ao sol, a cerca de 400 $m$ alt. É uma espécie pouco freqüente na RRP, sendo que a sua presença só foi registrada nos arredores do afloramento rochoso Corisquinho. Material examinado: trilha do Corisquinho, 3.VI.1997, Mynssen 139.

\section{Adiantum abscissum Schrad., Göt. Gel.} Anz. 872. 1824.

Planta terrícola, ocorre no interior da mata fechada, em ambientes mais sombreados e úmidos, próxima a córregos ou não, entre 190 e $600 \mathrm{~m}$ alt. Bastante freqüente e forma densas populações ao longo das trilhas.

Material examinado: trilha do Cambucá, 14.IX.1996, Braga 3484; id., 6.V.1997, Mynssen 96; trilha da Lagoa Seca, 27.V.1997, Braga 4091; trilha da Toca da Aranha, 22.X.1997, Mynssen 155; id., 26.VIII.1998, Santos 1060; id., 29.IX.1998, Mynssen 231.

3. Adiantum latifolium Lam., Encyc. 1: 43. 1783.

Planta terrícola, ocorre em ambientes parcialmente sombreados no sub-bosque, às margens das trilhas. Foi vista com mais freqüência nos arredores do afloramento rochoso do Corisquinho, entre 100 e $350 \mathrm{~m}$ alt. Material examinado: trilha do Cambucá, 30. XI.1996, Sylvestre 1243; trilha do Corisquinho, 3.VI.1997, Mynssen 126, 128, 129; trilha em frente à casa de máquinas, 6.I.2000, Mynssen
296; trilha do Palmiteiro passando pelo oleoduto da Petrobrás, 19.X.1999, Mynssen 293; trilha da Toca da Aranha, 22.X.1997, Mynssen 161.

4. Adiantum mynssenae Prado, Amer. Fern J. 94 (2): 112. 2004.

Planta terrícola, ocorre em ambiente parcialmente sombreado, em grandes populações às margens da trilha, onde a vegetação encontra-se mais alterada, entre 150 e $250 \mathrm{~m}$ alt. Prado (2003) descreveu esta espécie cujo tipo é da Reserva Rio das Pedras. Segundo este autor é endêmica da floresta atlântica dos estados de Minas Gerais, Rio de Janeiro e São Paulo. Material examinado: trilha do Cambucá, 14.IX.1996, Braga 3492; id., 6.V.1997, Mynssen 97; id., 26.VIII.1998, Dória 1; id., 13.VIII.1999, Mynssen 292; id., 16.VIII.2001, Mynssen 356, (holotypus RUSU; isotypus MBM, NY, RB, SP, UC).

5. Adiantum pulverulentum L., Sp. Pl. 2: 1096. 1753.

Planta terrícola, pode ocorrer tanto em ambientes mais secos e parcialmente ensolarados, quanto em locais úmidos e totalmente sombreados, entre 350 e $450 \mathrm{~m}$ alt.

Material examinado: trilha do Corisquinho, Mynssen 137, 3.VI.1997; trilha da Toca da Aranha, Braga 4439, 4.XI.1997.

6. Adiantum serratodentatum Willd., Sp. Pl. ed. $4,5: 445.1810$.

Planta terrícola de solo argiloso e vegetação alterada, ocorre em áreas muito expostas 
a luz solar, em campos com predominância de gramíneas, entre 200 e $350 \mathrm{~m}$ alt.

Material examinado: trilha do Corisquinho, 1.XII.1996, Braga 3685; trilha da Toca da Aranha, 26.VIII.1998, Mynssen 202.

7. Cheilanthes incisa Kunze ex Mett., Abh. Senckenberg. Naturf. Ges. 3. 44, tab. 3. 1859.

Planta rupícola, ocorre em ambiente sombreado, a cerca de $450 \mathrm{~m}$ alt. Segundo Mynssen \& Windisch (2002), esta espécie é muito pouco coletada, a ultima coleta que se tem registro data de 1940, e por se tratar de espécime de tamanho muito reduzido acreditase que passe desapercebido pelos coletores.

Material examinado: trilha da Toca da Aranha, 4.XI.1997, Braga 4427.

8. Doryopteris collina (Raddi) J. Sm., J. Bot. (Hooker) 4. 163. 1841.

Planta preferencialmente rupícola, em rochas com camada de húmus, eventualmente terrícola. Ocorre em áreas totalmente expostas ao sol ou parcialmente sombreadas, em ambientes mais secos, entre 150 e $450 \mathrm{~m}$ alt. Material examinado: trilha do Corisquinho 3. VI.1997, Mynssen 145, 146, 147; trilha do Mirante, 1.III.1997, Braga 3913; id., 12.VII.1997, Braga 4186; id., 26.VIII.1998, Santos 1063.

\section{Doryopteris lonchophora (Romer ex} Mett.) J. Sm., Hist. Fil. 289. 1875.

Planta preferencialmente rupícola em rochas com camada de húmus, raramente terrícola, sempre crescendo em ambientes muito sombreados e úmidos, entre 250 e $300 \mathrm{~m}$ alt.

Material examinado: trilha do Cambucá, 30.XI.1996, Sylvestre 1227; trilha da Lagoa Seca, 27.VIII.1998, Mynssen 222.

10. Doryopteris pedata (L.) Fée, Gen. Filic. [Mém. Foug. 5]: 133.

Planta terrícola, ocorre isoladamente em áreas parcialmente sombreadas no sub-bosque, entre 200 e $500 \mathrm{~m}$ alt. Observou-se ao longo do trabalho de campo, que existem espécimes com caracteres intermediários. Acredita-se que todos estes espécimes estariam circunscritos a um único táxon, por isso optou-se por um conceito amplo e não se considerou as categorias infra-específicas.

Material examinado: trilha do Cambucá, 14.IX.1996, Braga 3485; id., 25.VI.1998, Mynssen 193; id., 20.I.2000, Mynssen 315; trilha do Corisco, 6.I.2000, Mynssen 307; trilha do Corisquinho, 6.V.1997, Mynssen 114.

11. Doryopteris sagittifolia (Raddi) J. Sm., J. Bot. 4: 163. 1841.

Planta freqüentemente rupícola ou saxícola em rochas cobertas por húmus, ocasionalmente terrícola, sempre em ambientes sombreados e mais úmidos, entre 190 e $600 \mathrm{~m}$ alt.

Material examinado: trilha do Cambucá, 30.XI.1996, Sylvestre 1238; Poço do Cambucá, 6.V.1997, Mynssen 105; trilha do Corisco, 21.I.2000, Santos 1385; id., 21.I.2000, Mynnsen 326; trilha da Lagoa Seca, 27.V.1997, Braga 4092; trilha da Lagoa Seca, 27.VIII.1998, Mynssen 223.

12. Hemionitis tomentosa (Lam.) Raddi, Opusc. Sci. 3. 284. 1819.

Planta terrícola, que ocorre nas áreas onde a mata está mais aberta e o estrato herbáceo encontra-se exposto ao sol. Foi observada entre 70 e 350 m alt., sendo mais freqüente nos arredores do afloramento rochoso do Corisquinho.

Material examinado: trilha do Cambucá, 14.IX.1996, Braga 3489; id., 30.XI.1996, Sylvestre 1249; id., 23.III.1997, Bovini 1148; trilha do Corisquinho, 3.VI.1997, Mynssen 123; trilha da Toca da Aranha, 22.X.1997, Mynssen 153; trilha da Lagoa Seca, 26.V.1998, Mynssen 174.

13. Pityrogramma calomelanos (L.) Link, Handb. Gew. 3: 20. 1833.

Planta terrícola, em geral ocorre nas áreas mais expostas ao sol, ao longo das trilhas nas regiões mais degradadas, entre 70 e $350 \mathrm{~m}$ alt. Esta espécie apresenta a superfície laminar abaxial coberta por um indumento farináceo. Segundo Wollenweber \& Dietz (1981), trata- 
se de um composto fenólico lipofílico, secretado por pêlos glandulares, que teriam efeitos antibactericida e antifungicida. De acordo com Tryon \& Tryon (1982), esta espécie pode invadir regiões de pastagens e plantações.

Material examinado: trilha do Cambucá, 14.IX.1996, Braga 3491; trilha do Mirante, 6.V.1997, Mynssen 91.

14. Pteris altissima Poir., Encyc. 5: 722.1804.

Planta preferencialmente terrícola, de solos arenosos, podendo também ocorrer como saxícola. Em geral ocorre em grandes populações, sempre em ambientes úmidos e sombreados, às margens de córregos, entre 250 e $500 \mathrm{~m}$ alt. Os indivíduos jovens possuem lâminas 2pinado-pinatífidas, raque totalmente alada e segmentos muito estreitos, enquanto nos adultos a morfologia da lâmina é completamente diferente, o que poderia levar a uma identificação equivocada, caso fossem coletados isoladamente. Segundo Prado (2000), esta espécie possui uma grande variação morfológica.

Material examinado: trilha do Cambucá, 30. XI.1996, Sylvestre 1223, 1229; id., 23.III.1997, Braga 3945; trilha da Lagoa Seca, 26.V.1998, Mynssen 167, 170; id., 26.VIII.1998, Nonato 541; id., 27.VIII.1998, Mynssen 226.

15. Pteris angustata (Fée) C. V. Morton, Contrib. U.S. Nat. Herb. 2 (38):72. 1967.

Planta terrícola que ocorre em locais muito sombreados e úmidos, no interior de mata densa, entre cerca de 300 e $500 \mathrm{~m}$ alt.

Material examinado: trilha da Toca da Aranha, 11.I.1999, Mynssen 248, 253.

16. Pteris biaurita L., Sp. Pl. 2: 1076. 1753.

Planta terrícola que ocorre no interior de mata densa sombreada, entre cerca de 500 e $550 \mathrm{~m}$ alt., sendo pouco freqüente.

Material examinado: trilha da Lagoa Seca, 12.VII.1997, Braga 4218.

17. Pteris brasiliensis Raddi, Opusc. Sci. 3: 293. 1819.

Planta terrícola que ocorre em ambientes parcialmente sombreados, entre 250 e $350 \mathrm{~m}$ alt. Segundo Prado (2000), relaciona-se com Pteris denticulata Sw., mas pode ser facilmente distinguida pela raque não alada. Material examinado: trilha da Toca da Aranha, 26.VIII.1998, Mynssen 201; id., 29.IX.1998, Mynssen 232.

18. Pteris decurrens C. Presl, Delic. Prag. 1: 183. 1822.

Planta terrícola que ocorre no sub-bosque em áreas parcialmente sombreadas, entre 250 e $400 \mathrm{~m}$ alt. Esta espécie ocorre na América do Sul distribuindo-se amplamente na Região Sudeste brasileira. Assemelha-se Pteris biaurita, diferenciando-se por apresentar o padrão de venação com duas aréolas entre duas cóstulas adjacentes (Prado 2000).

Material examinado: trilha do Cambucá, 19.X.1996, Braga 3607; trilha da Lagoa Seca, 12.VII.1997, Braga 4198; trilha da Lagoa Seca, 26.V.1998, Mynssen 166.

19. Pteris denticulata Sw., Prodr. 129. 1788. Planta terrícola que habita locais parcialmente expostos ao sol, no sub-bosque em regiões mais secas. Foram observados indivíduos isolados a partir de cerca de 300 até $450 \mathrm{~m}$ alt.

Material examinado: trilha do Corisquinho, 3.VI.1997, Mynssen 138; trilha do Corisco, 6.I.2000, Mynssen 309.

20. Pteris leptophylla Sw., Kongl. Vetensk. Acad. Handl. 70. 1817.

Planta terrícola que ocorre isoladamente às margens da trilha, em local parcialmente sombreado. É pouco freqüente e foi observada apenas entre 150 e $200 \mathrm{~m}$ alt.

Material examinado: trilha da Casa de Máquinas, 6.I.2000, Mynssen 297.

21. Pteris splendens Kaulf., Enum. Filic. 186. 1824.

Planta terrícola que habita locais sombreados. É pouco freqüente e foi observada a cerca de $350 \mathrm{~m}$ alt.

Material examinado: trilha da Toca da Aranha, 11.I.1999, Mynssen 249. 
Referências: Tryon 1942, 1962; Brade 1965; Sehnem 1972; Wollenweber \& Dietz 1981; Prado 1993, 2000, 2003, 2004; Mynssen \& Windisch 2002.

\section{Schizaeaceae}

A família Schizaeaceae está constituída por quatro gêneros muito distintos, dos quais três estão representados no continente americano: Lygodium, Schizaea, Anemia (Tryon \& Tryon 1982).

\section{Chave para identificação das espécies}

1- Esporângios dispostos na margem modificada dos segmentos 4. Lygodium volubile

1'-Esporângios dispostos nas pinas basais modificados formando espigas

2- Nervuras areoladas

2. Anemia phyllitidis

2'-Nervuras livres

3- Lâmina pinada, pinas dimidiadas, raque coberta por longos pêlos avermelhados

1. Anemia mandioccana

3'-Lâmina pinado-pinatífida, pinas oblongas a elípticas, raque coberta por pêlos castanhos a nigrescentes 3. Anemia villosa

1. Anemia mandioccana Raddi, Opusc. Sci.

3.282.1819.

Planta terrícola, rupícola ou saxícola. Habita locais úmidos e sombreados próximos a cursos d'água ou não, entre 70 e $350 \mathrm{~m}$ alt.

Material examinado: trilha do Cambucá, 30.XI.1996, Sylvestre 1253; trilha da Lagoa Seca, 12.VII.1997, Braga 4195; id., 26.VIII.1998, Santos 1068; trilha da Toca da Aranha, 26.V.1998, Mynssen 163.

2. Anemia phyllitidis (L.) Sw., Syn. Fil. 155. 1806.

Planta terrícola, freqüente nas margens de trilhas, em ambientes sombreados ou mais expostos a incidência solar, entre 70 e $500 \mathrm{~m}$ alt. Material examinado: trilha do Corisco e rio Grande, Lira Neto 339, 18.VIII.1996; trilha do Corisquinho, Mynssen 130, 3.VI.1997.

3. Anemia villosa Willd., Sp. Pl. ed. 4, 5:92. 1810. Planta terrícola que ocorre preferencialmente em ambientes ensolarados ou pouco sombreados, a partir de 70 até $450 \mathrm{~m}$ alt.

Material examinado: trilha do Corisquinho, 3.VI.1997, Mynssen 143; trilha do Mirante, 26.V.1998, Mynssen, 179.
4. Lygodium volubile Sw., J. Bot. (Schrader) 1801 (1): 304.1803.

Planta terrícola que ocorre ao longo das trilhas, geralmente associada a ambientes mais abertos e expostos a luz solar, entre 70 e 400 $\mathrm{m}$ alt. É uma espécie escandente e volúvel pela raque. Freqüentemente são encontrados indivíduos jovens crescendo em barrancos ou nas proximidades dos caminhos.

Material examinado: trilha do Cambucá, 14.IX.1996, Braga 3486; id., 30.XI.1996, Sylvestre 1246; id., 3.VI.1997, Mynssen 119; trilha da Toca da Aranha, 22.X.1997, Mynssen 162; id., 26.VIII.1998, Mynssen 197.

Referências: Sehnem 1974; Mickel \& Beitel 1988; Tryon \& Stolze 1989.

\section{Selaginellaceae}

A família Selaginellaceae está distribuída em quase todo o mundo e é composta somente pelo gênero Selaginella com cerca de 700 espécies, das quais aproximadamente 270 ocorrem nas Américas (Tryon \& Tryon 1982). 


\section{Chave para identificação das espécies}

1- Ramos caulinares articulados

2- Microfilo axilar com base longo auriculada 6. Selaginella sulcata

2'- Microfilo axilar com base obtusa 5. Selaginella suavis

1'- Ramos caulinares não articulados

3- Microfilo com margens longamente ciliadas, microfilo lateral com ápice obtuso

3'-Microfilos com margens inteiras ou curtamente ciliadas, microfilo lateral com ápice agudo

4- Microfilos laterais e axilares com margens curtamente ciliadas ..... 4. Selaginella muscosa 4'-Microfilos laterais e axilares nunca com margens ciliadas

5- Microfilos dorsais com ápices aristados, os laterais contíguos

1. Selaginella contigua

5'- Microfilos dorsais com ápices acuminados, os laterais afastados entre si 2. Selaginella decomposita

1. Selaginella contigua Baker, J. Bot. 22 (162): 295. 1884.

Planta terrícola, encontrada em barrancos, em locais sombreado e úmido, a cerca de $600 \mathrm{~m}$ alt.

Material examinado: trilha do Corisco, 21.I.2000, Santos 1382.

2. Selaginella decomposita Spring, in Martius Fl. Bras. 1(2): 123. 1840.

Planta rupícola, revestindo completamente a face vertical de um grande afloramento rochoso em ambiente muito úmido e sombreado, entre 250 e $300 \mathrm{~m}$ alt.

Material examinado: trilha da Lagoa Seca, 13.VIII.1999, Mynssen 292 B.

3. Selaginella jungermannioides (Gaudich.) Spring, Bull. Acad. Roy. Sci. Belgique 10: 143. 1843.

Planta rupícola, revestindo completamente a face vertical de um grande afloramento rochoso em ambiente muito úmido $\mathrm{e}$ sombreado, entre 250 e $300 \mathrm{~m}$ alt. Os microfilos possuem coloração verde azulada e os rizóforos ventrais a deixam ligeiramente afastada de seu substrato.

Material examinado: trilha do Cambucá, 30.XI.1996, Sylvestre 1228; trilha da Lagoa Seca, 26.V.1998, Mynssen 169; id., 26.VIII.1998, Santos 1071.
4. Selaginella muscosa Spring, in Martius Fl. Bras. 1(2): 120. 1840.

Planta rupícola sobre rochas com camada húmus às margens do rio Grande, ou como terrícola em barrancos argilosos que margeiam as trilhas. Observados com freqüência em ambientes muito úmidos e sombreados, entre 70 e $450 \mathrm{~m}$ alt.

Material examinado: trilha da Cachoeira após a entrada da trilha do Corisco, 21.I.2000, Santos 1390; trilha do Cambucá, 30.XI.1996, Sylvestre 1251; id., 26.VIII.1998, Santos 1067; id., 27.VIII.1998, Mynssen 213.

5. Selaginella suavis (Spring) Spring, Bull. Acad. Sci. Brux. 10: 229. 1843.

Planta preferencialmente rupícola, podendo ocorrer como terrícola, estendendo-se a barrancos argilosos, em ambientes muito úmidos e sombreados. É encontrada freqüentemente próxima a pequenos cursos d'água que cortam as trilhas, ocorrendo entre 100 e $350 \mathrm{~m}$ alt.

Material examinado: trilha do Cambucá, 30.XI.1996, Sylvestre 1248; id., 26.V.1998, Mynssen 180; id., 27.VIII.1998, Mynssen 212.

6. Selaginella sulcata (Desv. ex Poir.) Spring, Flora 20 (2): 126. 1837.

Planta terrícola, em solo argiloso ou argiloarenoso, em ambientes sombreados, úmidos ou pouco secos, ocorrendo de 100 a $600 \mathrm{~m}$ alt. $\mathrm{O}$ caule pode ter coloração vinácea. 
Material examinado: trilha do Corisco, 6.I.2000, Mynssen 312, 325; trilha do Corisquinho, 1.XII.1996, Braga 3681; id., 26/04/ 1997, Braga 3979; trilha da Lagoa Seca, 26.VIII.1998, Nonato 540.

Referências: Alston 1936; Alston et al. 1981.

\section{Thelypteridaceae}

A família Thelypteridaceae é uma das maiores famílias de Pteridóftas com cerca de 1.000 espécies, a maioria distribuída nas regiões tropicais e sub-tropicais (Smith 1990).

\section{Chave para identificação das espécies}

1- Lâmina 3-pinado-pinatífida 1. Macrothelypteris torresiana

1'-Lâmina pinada ou pinado-pinatífida

2- Nervura totalmente livre

3- Pinas com margens retroflexas

3. Thelypteris opposita

3'- Pinas com margens não retroflexas

4- Planta terrícola, segmentos com 8-11 pares de nervuras partindo da cóstula 4. Thelypteris polypodioides 4'-Planta rupícola ou saxícola, segmentos com 2-4 pares de nervuras partindo da cóstula 5. Thelypteris ptarmica (T. ptarmica var. asplenioides)

2'-Nervura areolada ou pelo menos com o par de basal unindo-se a uma nervura que se dirige a base do enseio

5- Caule reptante, lâmina pinado-pinatífida

2. Thelypteris dentata

5'-Caule ereto, lâmina pinada

6- Soros lineares ou falciformes

6. Thelypteris serrata

6'- Soros arredondados

7. Thelypteris vivipara

\section{Macrothelypteris torresiana (Gaudich.)}

Ching, Acta Phytotax. Sin. 8: 310. 1963.

Planta terrícola, ocorre em ambientes ensolarados ou pouco sombreados. É mais freqüente no bosque degradado, entre 100 à $400 \mathrm{~m}$ alt. Segundo Mickel \& Beitel (1988), esta espécie foi introduzida nos neotrópicos e rapidamente se expandiu. Atualmente observase seu crescimento de forma subespontânea em locais abertos e expostos ao sol. É facilmente distinta pela lâmina 3-pinadopinatífida e pelo seu indumento constituído de tricomas alvos brilhantes nas duas faces.

Material examinado: trilha do Cambucá, 14.IX.1996, Braga 3487; trilha da Lagoa Seca, 26.V.1998, Mynssen 181, 183.

2. Thelypteris dentata (Forssk.) E. St. John, Amer. Fern J. 26(2): 44.1936.

Planta terrícola, ocorre em áreas bastante degradadas e expostas ao sol, entre 200 e 300 $\mathrm{m}$ alt.
Material examinado: trilha do Cambucá, 6.I. 2000, Mynssen 289; trilha do Corisco, 6.I.2000, Mynssen 306; trilha do Corisquinho, 3.VI.1997, Mynssen 124; id., 6.I.2000, Mynssen 301.

3. Thelypteris opposita (Vahl) Ching, Bull. Fan Mem. Inst. Biol. 10: 251. 1941.

Planta terrícola freqüentemente encontrada no sub-bosque em locais parcialmente sombreados e úmidos, ou mais expostos ao sol e secos. Foi observada entre 150 e $450 \mathrm{~m}$ alt.

Material examinado: trilha do Cambucá, 30.XI.1996, Sylvestre 1242; id., 22.III.1999, Mynssen 256; id., 6.I.2000, Mynssen 308.

4. Thelypteris polypodioides (Raddi) C. F. Reed, Phytologia 309. 1968.

Planta terrícola que ocorre no sub-bosque em áreas parcialmente sombreadas. Foi observada entre 250 e $450 \mathrm{~m}$ alt.

Material examinado: trilha da Toca da Aranha, 29.IX.1998, Mynssen 237. 
5. Thelypteris ptarmica var. asplenioides (Sw.) Ponce, Darwiniana 33 (1-4): 262. 1995.

Planta rupícola ou saxícola, ocorre em populações ou isolada em ambientes bastante sombreados e úmidos, às margens do rio Grande e córregos, entre 100 e $500 \mathrm{~m}$ alt. Segundo Ponce (1998), Thelypteris ptarmica var. ptarmica distingue-se por possuir soros elipticos ou lineares, sem indúsio e lâminas com tricomas uncinulados curtos.

Material examinado: Poço do Cambucá, 14.IX.1996, Bovini 1042; id., 19.X.1996, Bovini 1077; id., 30.XI.1996, Sylvestre 1236; id., 6.V.1997, Mynssen 100, 101; trilha do Corisco, 21.I.2000, Mynssen 310; trilha da Lagoa Seca, 26.V.1998, Mynssen 171; margem do rio Grande, proximidades de Lages, 20.I.2000, Nonato 685.

\section{Thelypteris serrata (Cav.) Alston, Kew} Bull. 1932: 309. 1932.

Planta terrícola que habita locais parcialmente sombreados, onde o solo possui uma espessa camada de matéria orgânica e freqüentemente encontra-se inundado. Apenas observada na localidade conhecida como Lagoa Seca, a cerca de $800 \mathrm{~m}$ alt.
Material examinado: trilha da Lagoa Seca, 13.VIII.1999, Mynssen 289.

7. Thelypteris vivipara (Raddi) C. F. Reed, Phytologia 17.309. 1968.

Planta terrícola, habita locais úmidos e parcialmente sombreados. É comumente encontrada em no interior do sub-bosque ou às margens de cursos d'água, entre 100 e $300 \mathrm{~m}$ alt.

Material examinado: trilha da Toca da Aranha, 22.X.1997, Mynssen 158; 29.IX.1998, Mynssen 228.

Referências: Brade 1972; Sehnem 1979a, Smith 1983; Mickel \& Beitel 1988; Proctor 1989; Smith 1990; Tryon \& Stolze 1992; Ponce 1998; Salino \& Semir 2004.

\section{Vittariaceae}

A família Vittariaceae é constituída por cerca de 100 espécies e dez gêneros, dos quais sete ocorrem nas Américas. Possui distribuição pantropical, estendendo-se até regiões temperadas. É predominantemente epífita, podendo também ocorrer sobre rochas (Nonato \& Windisch 2004).

\section{Chave para identificação das espécies}

1- Célula apical das paráfises infundibuliformes

1. Radiovittaria stipitata

1'-Célula apical das paráfises filiformes ou levemente clavadas

2. Vittaria graminifolia

1. Radiovittaria stipitata (Kunze) E. H. Crane, Syst. Bot. 22 (3): 514.1997.

Planta epífita que ocorre em local úmido e sombreado no interior da mata. Foi observada a cerca de $300 \mathrm{~m}$ alt. Segundo Nonato \& Windisch (2004), os indivíduos de R. stipitata ocorrem preferencialmente em florestas pluviais sombreadas e úmidas.

Material examinado: trilha da Lagoa Seca, 26.VIII.1998, Nonato 539.

2. Vittaria graminifolia Kaulf., Enum. Filic. 192. 1824.

Planta preferencialmente epífita, ocorrendo também sobre rochas úmidas cobertas por hú- mus, em locais muito sombreados e úmidos, a cerca de $300 \mathrm{~m}$ alt. De acordo com Nonato \& Windisch(2004), ocorre preferencialmentenas florestas pluviais tropicais. Assemelha-se a Vittaria lineata, diferenciando por apresentar paráfise com célula apical alargada e esporos triletes.

Material examinado: trilha da Toca da Aranha, 26.VIII.1998, Nonato 537.

Referências: Sehnem 1967 b; Windisch \& Nonato 1999; Nonato \& Windisch 2004. 


\section{Agradecimentos}

A Dra. Regina Helena Potsch Andreata e Dra. Lana da Silva Sylvestre pelo apoio no desenvolvimento deste trabalho e valiosas críticas e sugestões. Aos pesquisadores pela conferência de algumas identificações: Dr. Alexandre Salino (Thelypteridaceae), Dra. Fabiana Regina Nonato (Vittariaceae), Dra. Irene Fernandes (Cyatheaceae), Dr. Jefferson Prado (Adiantum e Pteris), Dra. Lana da Silva Sylvestre (Aspleniaceae). Aos Profs. João Marcelo Alvarenga Braga e Massimo Giuseppe Bovini pelo companherismo e auxílio nas expedições. Aos curadores dos herbários visitados. Aos coordenadores da pós-graduação do Museu Nacional/UFRJ e aos dirigentes da Universidade Santa Úrsula e Jardim Botânico do Rio de Janeiro, pelo apoio concedido para o desenvolvimento deste trabalho. À Coordenação de Apoio do Pessoal de Ensino Superior (CAPES) pela bolsa de mestrado concedida.

\section{REFERÊNCIAS BIBLIOGRÁFICAS}

Agrofoto Aerofotogrametria S/A 1999. Levantamento planialtimétrico da RPPN-Reserva Rio das Pedras, km 445,5 da BR 101 (Rio-Santos). Escala 1:10.000, Município de Mangaratiba, Estado do Rio de Janeiro, RJ.

Alston, A. H. G. 1936. The Brazilian species of Selaginella. Repertorium Specierum Novarum Regni Vegetabilis 40: 303-319. 1958. The Brazilian species of Elaphoglossum. Boletim da Sociedade Broteriana 32 (2): 1-32.

Alston, A. H. G.; Jermy, A. C. \& Rankin, J. M. 1981. The genus Selaginella in tropical South America. Bulletin of the British Museum (Natural History), Botany 9 (4): 233-330.

Andersen, E. \& Øllgaard, B. 1996. A note some morphological terms of the leaf in the Gleicheniaceae. American Fern Journal 86 (2): 52-57.

Boer, J. G. W. 1962. The new world species of Trichomanes sect. Didymoglossum and Microgonium. Acta Botanica Neerlandica 11: 277-330.
Brade, A. C. 1956. A Flora do Parque Nacional do Itatiaia. Parque Nacional do Itatiaia 5: $1-85$.

1960-61. O gênero Elaphoglossum (Polypodiaceae) no Brasil - I. Chave para determinar as espécies brasileiras. Rodriguésia 23/24 (35/36): 21-48. 1965. Contribuição para o conhecimento das espécies brasileiras do gênero Doryopteris (Polypodiaceae). Arquivos do Jardim Botânico do Rio de Janeiro 18 (2): 39-72.

1971. O gênero Polybotrya no Brasil - I. Bradea 1 (9): 57-67, il.

1972. O gênero Dryopteris (Pteridophyta) no Brasil e sua divisão taxonômica. Bradea 1 (22): 192-261.

Camus, J. M. 1990. Marattiaceae. Pp. 101144. In: K.U. Kramer \& P.S. Green 1990. The Families and Genera of Vascular Plants. Vol 1 Pteridophytes and Gymnosperms. Springer Verlag. New York.

Cislinki, J. 1996. O gênero Diplazium Sw. (Dryopteridaceae, Pteridophyta) no Estado do Paraná, Brasil. Acta Botânica Brasilica 10 (1): 59-77.

Crane, E. H. 1997. A revised circumscription of the genera of the fern family Vittariaceae. Systematic Botany 22 (3): 509-517.

Evans, A. M., 1969. Interspecific relationships in the Polypodium pectinatum-plumula complex. Annals of the Missouri Botanical Garden 55 (3): 193-293.

Fernandes, I. 1997. Taxonomia e fitogeografia de Cyatheaceae e Dicksoniaceae nas regiões sul e sudeste do Brasil. Tese de Doutorado, Instituto de Biociências da Universidade de São Paulo.

Hensen, R. V. 1990. Revision of the Polypodium loriceum complex (Filicales, Polypodiaceae). Nova Hedwigia 50 (3-4): 279-336.

Kazmirczak, C. 1999. A família Blechnaceae (Presl) Copel. (Pteridophyta) no Rio Grande do Sul, Brasil. Dissertação de mestrado, Universidade Federal do Rio Grande do Sul. 
Kramer, K. U. 1990. Gleicheniaceae. Pp. 145152. In: K. U. Kramer. \& P. S. Green 1990. The Families and Genera of Vascular Plants. Vol. 1 Pteridophytes and Gymnosperms. Springer Verlag. New York.

Kramer, K. U. 1990. Lomariopsidaceae. Pp. 164-170. In: K. U. Kramer. \& P. S. Green 1990. The Families and Genera of Vascular Plants. Vol. 1 Pteridophytes and Gymnosperms. Springer Verlag. New York.

Kramer, K. U. 1990. Nephrolepidaceae. Pp. 188-190. In: K. U. Kramer. \& P. S. Green, 1990. The Families and Genera of Vascular Plants. Vol. 1 Pteridophytes and Gymnosperms. Springer Verlag. New York.

Kramer, K. U.; Holtum, R. E.; Moran, R. C. \& Smith, A. R. 1990. Pp. 101-144. Dryopteridaceae. In: K. U. Kramer \& P. S. Green, 1990. The Families and Genera of Vascular Plants. Vol. 1 Pteridophytes and Gymnosperms. Springer Verlag. New York.

Kramer, K. U. \& Green, P. S. 1990. The Families and Genera of Vascular Plants. Vol. 1 Pteridophytes and Gymnosperms. Springer Verlag. New York.404 p.

Labiak, P. H. \& Prado, J. 1998. Pteridófitas epífitas da Reserva Volta Velha, Itapoá Santa Catarina, Brasil. Boletim do Instituto de Botânica 11: 1-79.

Lellinger, D. B. 1987. The Disposition of Trichopteris (Cyatheaceae). American Fern Journal 77 (3): 90-94.

León, B. 1992. A Taxonomic revision of the fern genus Campyloneurum (Polypodiaceae). Tese de Doutorado. Museo de Historia Natural, Universidad Nacional Mayor de San Marcos, Peru.

Mickel, J. T. \& Beitel, J. M. 1988. Pteridophyte Flora of Oaxaca, Mexico. Memoirs of the New York Botanical Garden 46: 568p.

Moran, R. C. 1987. Monograph of the Neotropical Fern genus Polybotrya (Dryopteridaceae). Bulletin of the Illinois Natural History Survey 34 (1): 1-138. . 1991. Monograph of the Neotropical Fem genus Stigmatopteris (Dryopteridaceae). Annals of Missouri
Botanical Garden 78: 857-914.

.2000. Monograph of the neotropical species of Lomariopsis (Lomariopsisdaceae). Brittonia 52 (1): 55-111.

Mori, S. A.; Boom, B. M. \& Prance, G. T. 1981. Distribution patterns and conservation of easterns brazilian coastal forest tree species. Brittonia 33 (2): 233-245.

Morton, C. V. 1958. Observations on cultivated ferns, V. The species and forms of Nephrolepis. American Fern Journal 48:18-27.

Murillo, M. T. 1968. Blechnum subgénero Blechnum en Sur América, con especial referencia a las especies de Colombia. Nova Hedwigia 16: 329-366, t. 110-147

Mynssen, C. M. \& Sylvestre, L. S. 2001. Pteridófitas do Morro Mundo Novo, Rio de Janeiro, RJ. Eugeniana 25: 26 - 31.

Mynssen, C. M.; Sylvestre, L. S \& Andreata, R. H. P. 2002. Pteridófitas das matas de encosta do Jardim Botânico do Rio de Janeiro. Pesquisas (Botânica) 52: 47-87.

Mynssen, C. M. \& Windisch, P. G. 2002. Cheilanthes incisa Kunze ex Mett., uma espécie rara da Mata Atlântica do Estado do Rio de Janeiro, Brasil. Bradea 7 (49): 335-337.

Nonato, F. R. \& Windisch, P. G. 2004. Vittariaceae (Pteridophyta) do sudeste do Brasil. Revista Brasileira de Botânica 27 (1): 149-161.

Ølgaard, B. \&Windisch, P. G. 1987. Sinopse das Lycopodiáceas do Brasil. Bradea 1 (5): 1-43.

Øllgaard, B. 1990. Lycopodiaceae. Pp. 188190. In: K. U. Kramer, \& P. S. Green, 1990. The Families and Genera of VascularPlants. Vol 1 Pteridophytes and Gymnosperms. Springer Verlag. New York.

Pérez-Garcia, B. 1993. Pteridofitas: Marattiaceae. Flora de Mexico 6 (1): 1-12.

Pichi-Sermolli, R. E. G. 1996. Authors of scientific names in Pteridophyta. Royal Botanical Garden, Kew. 78p.

Ponce, M. M. 1998. Novedades en Thelypteris subg. Amauropelta (Thelypteridaceae) de Brasil y Paraguay. Novon 8 (3): 275-279. 
Prado, J. 1993. New Name and New Status in Brasilian Pteris L. (Pteridaceae). American Fern Journal 83 (4): 131-134. 2000. The genus Pteris L (Pteridaceae) in Brazil. Boletim do Instituto de Botânica 13: 103-199. 2003. New species in Adiantum from Brazil. American. Fern Journal 93 (2): 76-80.

2004. Nomenclatural corrections in Adiantum. American Fern Journal 94 (2): 112.

Price, M. G. 1983. Pecluma, a new tropical american fern genus. American Fern Journal 73 (3): 109-116.

Proctor, G. R. 1989. Ferns of Puerto Rico and the Virgin Islands. Memoirs of the New York Botanical Garden 53: 1-389.

Rizzini, C. T. 1953-54. Flora Organensis. Lista Preliminar dos Cormophyta da Serra dos Órgãos. Arquivos do Jardim Botânico do Rio de Janeiro 13: 118-246.

Salino, A. \& Semir, J. 2004. Thelypteris subg. Meniscium (Thelypteridaceae - Pterophyta) no estado de São Paulo, Brasil. Revista Brasileira de Botânica 27 (1):103-113.

Santos, M. G.; Sylvestre, L. S. \& Araújo, D. S. D. 2004. Análise Florística das pteridófitas do Parque Nacional da Restinga de Jurubatiba, Rio de Janeiro, Brasil. Acta Botânica Brasilica 18 (2): 271-280.

Sehnem, A. 1963. O gênero Asplenium nos estados de Santa Catarina e Rio Grande do Sul. Sellowia 15: 9-37.

1967b. Maratiáceas. In: R. REITZ.

Flora Ilustrada Catarinense. Itajaí, Herb.

Barbosa Rodrigues, 16p.

1967d. Vitariáceas. In: R. Reitz.

Flora Ilustrada Catarinense. Itajaí, Herb.

Barbosa Rodrigues, $17 \mathrm{p}$.

. 1968a. Aspleniáceas. In: R. Reitz.

Flora Ilustrada Catarinense. Itajaí, Herb.

Barbosa Rodrigues, 96p.

1968b. Blecnáceas. In: R. Reitz.

Flora Ilustrada Catarinense. Itajaí, Herb.

Barbosa Rodrigues, 90p. 1970a. Gleiqueniáceas. In: R. Reitz.

Flora Ilustrada Catarinense. Itajaí, Herb.

Barbosa Rodrigues, 37p. 1970b. Polipodiáceas. In: R. Reitz.

Flora Ilustrada Catarinense. Itajaí, Herb.

Barbosa Rodrigues, 173p. 1971. Himenofiláceas. In: R. Reitz.

Flora Ilustrada Catarinense. Itajaí, Herb.

Barbosa Rodrigues, 98p. 1972. Pteridáceas. In: R. Reitz. Flora Ilustrada Catarinense. Itajaí, Herb. Barbosa Rodrigues, 244p.

1974. Esquizeáceas. In: R. Reitz.

Flora Ilustrada Catarinense. Itajaí, Herb.

Barbosa Rodrigues, 78p.

Sehnem, A. 1978. Ciateáceas. In: R. Reitz. Flora Ilustrada Catarinense. Itajaí, Herb. Barbosa Rodrigues, 166p. 1979a. Aspidiáceas. In: R. Reitz. Flora Ilustrada Catarinense. Itajaí, Herb. Barbosa Rodrigues, 356p. 1979b. Davaliáceas. In: R Reitz. Flora Ilustrada Catarinense. Itajaí, Herb. Barbosa Rodrigues, 18p.

Smith, A. R. 1983. Polypodiaceae Thelypteridoideae. In: G. Harling \& B. Sparre (Eds.). Flora of Ecuador 18: 1-148.

Smith, A. R. 1990. Thelypteridaceae. Pp. 263272. In: K. U. Kramer \& P. S. Green 1990. The Families and Genera of Vascular Plants. Vol 1 Pteridophytes and Gymnosperms. Springer Verlag. New York.

Smith, A. R. \& Moran, R. C. 1987. New Combinations in Megalastrum (Dryopteridaceae). American Fern Journal 77 (4): 124-130.

Smith, L. B. 1962. Origins of the flora of southern Brazil. Contributions from the United States National Herbarium 35 (3): 215-249.

Sota, E. R. De La. 1965. Las especies escamosas del genero Polypodium L. ( $s$. str.) en Brasil. Revista del Museo de La Plata. 42 (11): 243-271.

Sylvestre, L. S. 2001. Revisão taxonômica das espécies da família Aspleniaceae A. B. Frank ocorrentes no Brasil. Tese de 
Doutorado, Instituto de Biociências da Universidade de São Paulo. 1997a. Pteridófitas da Reserva Ecológica Macaé de Cima. Pp. 40-52. In: H. C. Lima \& R. R. Guedes-Bruni (Orgs.) Serra de Macaé de Cima: Diversidade Florística e Conservação de Mata Atlântica. Jardim Botânico do Rio de Janeiro. 1997b. Pteridophyta. In: M. C. M Marques. Mapeamento da cobertura vegetal e listagem das espécies ocorrentes na Área de Proteção Ambiental de Cairuçu, Município de Parati, RJ. Jardim Botânico do Rio de Janeiro - Série Estudos e Contribuições 13: 44-49.

Tryon, R. M. 1942. A revision of the genus Doryopteris. Contributions from the Gray Herbarium of Harvard University 143: 180.

1960. A review of genus Dennstaedtia in America. Contributions from the Gray Herbarium of Harvard University 187: 23-52.

Tryon, R. M. 1962. The fern genus Doryopteris in Santa Catarina and Rio Grande do Sul, Brazil. Anais Bot. Herbário Barbosa Rodrigues 14: 52-59.

1964. The Ferns of Peru Polypodiaceae (Dennstaedtiaceae to Oleandreae). Contributions from the Gray Herbarium of Harvard University 194: 1253.

1972. Endemic areas and geographic speciation in tropical american ferns. Biotropica 4 (3):121-131.

Tryon, R. M. \& Conant, D. S. 1975. The ferns of Brazilian amazonia. Acta Amazonica $5(1): 23-34$.

Tryon, R. M. \& Stolze, R. G. 1989. Pteridophyta of Peru, part II. 13. Pteridaceae - 15. Dennstaedtiaceae. Fieldiana: Botany, new series. 22: 1-145. 1991. Pteridophyta of Peru, part IV.

17. Dryopteridaceae. Fieldiana: Botany, new series. 27: 1-176.
1992. Pteridophyta of Peru, part III. 16. Thelypteridaceae. Fieldiana: Botany, new series. 29: 1-80.

1993. Pteridophyta of Peru, part V, 18. Aspleniaceae - 21. Polypodiaceae. Fieldiana: Botany, new series. 32: 1-190.

Tryon, R. M. \& Tryon A. F. 1982. Ferns and Allied Plants, with Special Reference to Tropical America. New York, Springer Verlag. 857 p.

Vellozo, J. M. C. 1825-1827. Cryptogamia. Pp. 443-461. In: Florae Fluminensis... Flumine Januario: Ex Tipographia Nacional.

Vidal, U. de A. 1995. A família Bromeliaceae na Reserva Ecológica Rio das Pedras, Mangaratiba, Rio de Janeiro, Brasil. Dissertação de Mestrado. Museu Nacional/Universidade Federal do Rio de Janeiro.

Windisch, P. G. 1992 a. Pteridófitas da região Norte-ocidental do estado de São Paulo: guia para estudo e excursões. $2^{a}$ edição. Universidade Estadual Paulista, São José do Rio Preto. 110 p. ilus.

.1992 b. Trichomanes crispum L. (Pteridophyta, Hymenophyllaceae) and allied species. Bradea 6 (12): 78-117. 1994. Pteridófitas do estado de Mato Grosso: Gleicheniaceae. Bradea 6 (37): 304-311.

1995. Pteridófitas do estado de Mato Grosso: Marattiaceae. Bradea 6 (46): 396399.

Windisch, P. G. 1996. Pteridófitas do estado de Mato Grosso: Hymenophyllaceae. Bradea 6 (47): 400-423.

Windisch, P. G. \& Nonato, F. R. 1999. Pteridófitas do estado de Mato Grosso, Brasil: Vittariaceae. Acta Botânica Brasilica 13 (3): 291-297.

Wollenweber, E. \& Dietz, H. V. 1981. Scale insects feeding on farinose species of Pityrogramma. American Fern Journal 71: 10-12. 